\title{
Development of Materials for Open-Cycle Magnetohydrodynamics (MHD): Ceramic Electrode, Final Report
}
J. L. Bates
D. D. Marchant

September 1986

Prepared for the U.S. Department of Energy under Contract DE-AC06-76RLO 1830

Pacific Northwest Laboratory Operated for the U.S. Department of Energy by Battelle Memorial Institute 


\title{
DISCL.AIMER
}

This report was prepared as an account of work sponsored by an agency of the United States Government. Neither the United States Government nor any agency thereof, nor any of their employees, makes any warranty, express or implied, or assumes any legal liability or responsibility for the accuracy, completeness, or usefulness of any information, apparatus, product, or process disclosed, or represents that its use would not infringe privately owned rights. Reference herein to any specific commercial product, process, or service by trade name, trademark, manufacturer, or otherwise, does not necessarily constitute or imply its endorsement, recommendation, or favoring by the United States Government or any agency thereof. The views and opinions of authors expressed herein do not necessarily state or reflect those of the United States Government or any agency thereof.

\author{
PACIFIC NORTHWEST LABORATORY \\ operated by \\ BATTELLE \\ for the \\ UNITED STATES DEPARTMENT OF ENERGY \\ under Contract DE-AC06-76RLO 1830
}

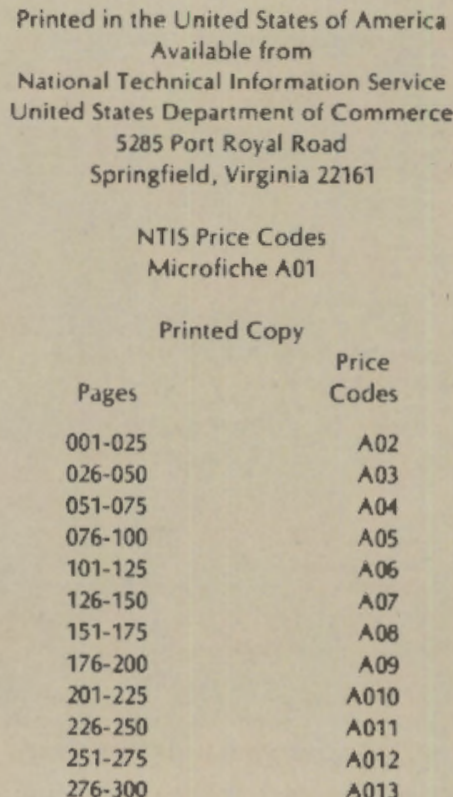


DEVELOPMENT OF MATERIALS FOR OPEN-CYCLE MAGNETOHYDRODYNAMICS (MHD): CERAMIC

ELECTRODE, FINAL REPORT

J. L. Bates

D. D. Marchant

September 1986

Prepared for the U.S. Department of Energy under Contract DE-AC06-76RLO 1830

Pacific Northwest Laboratory

Richland, Washington 99352 


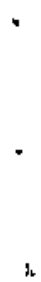




\section{ABSTRACT}

Pacific Northwest Laboratory, supported by the U.S. Department of Energy, developed advanced materials for use in open-cycle, closed cycle magnetohydrodynamics (MHD) power generation, an advanced energy conversion system in which the flow of electrically conducting fluid interacts with an electric field to convert the energy directly into electricity. The purpose of the PNL work was to develop electrodes for the MHD channel. Such electrodes must have: 1) electrical conductivity above $0.01(\mathrm{ohm}-\mathrm{cm})^{-1}$ from near room temperature to $1900 \mathrm{~K}, 2)$ resistance to both electrochemical and chemical corrosion by both slag and potassium seed, 3) resistance to erosion by high-velocity gases and particles, 4) resistance to thermal shock, 5) adequate thermal conductivity, 6) compatibility with other channel components, particularly the electrical insulators, 1) oxidation-reduction stability, and 8) adequate thermionic emission. This report describes the concept and development of high-temperature, graded ceramic composite electrode materials and their electrical and structural properties. 


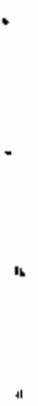

.

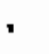




\section{CONTENTS}

ABSTRACT

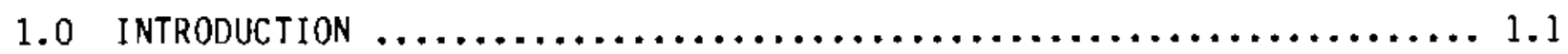

2.0 GRADED CERAMIC COMPOSITE ELECTRODE $\ldots \ldots \ldots \ldots \ldots \ldots \ldots \ldots \ldots \ldots \ldots$

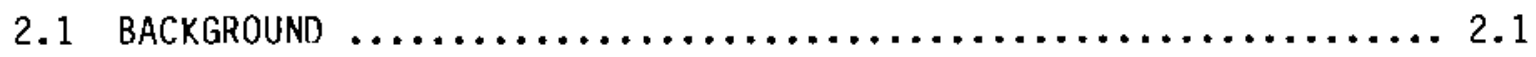

2.2 MATERIALS SELECTION $\ldots \ldots \ldots \ldots \ldots \ldots \ldots \ldots \ldots \ldots \ldots \ldots \ldots \ldots \ldots \ldots \ldots \ldots \ldots \ldots \ldots \ldots$

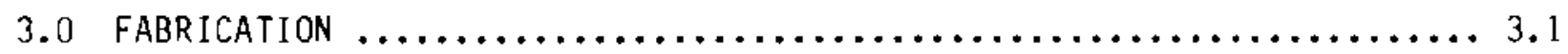

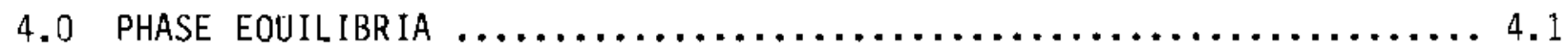

5.0 ELECTRICAL CONDUCTIVITY $\ldots \ldots \ldots \ldots \ldots \ldots \ldots \ldots \ldots \ldots \ldots \ldots \ldots \ldots \ldots \ldots \ldots \ldots$

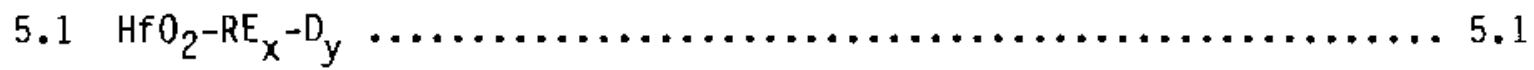

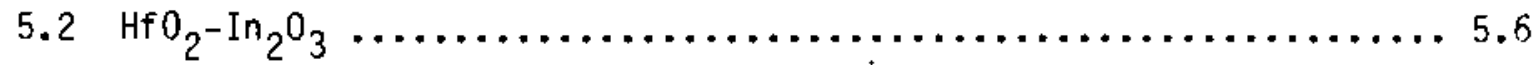

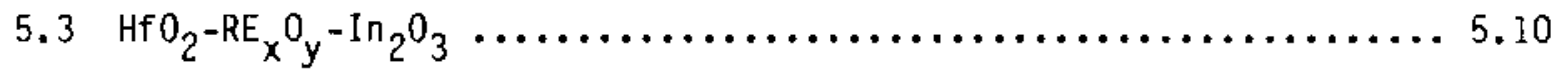

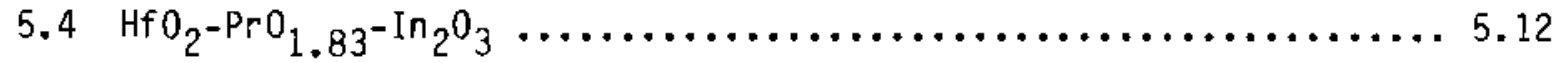

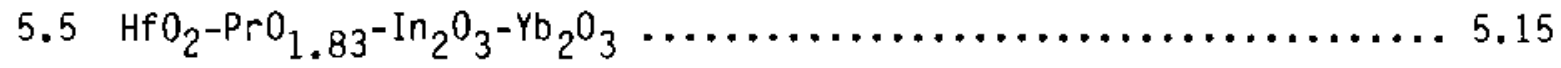

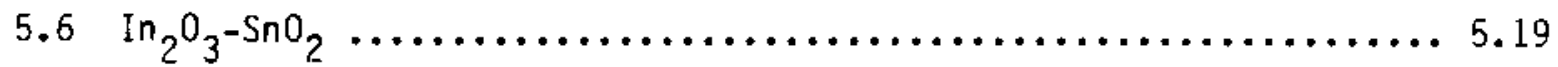

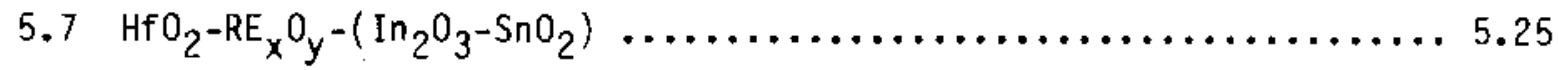

6.0 MHD TEST CHANEL $\ldots \ldots \ldots \ldots \ldots \ldots \ldots \ldots \ldots \ldots \ldots \ldots \ldots \ldots \ldots \ldots \ldots \ldots \ldots$

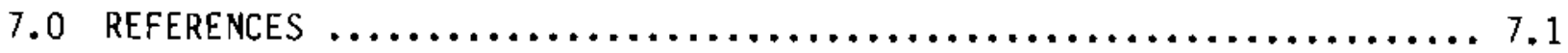


FIGURES

1 Concept of Graded Composite Electrode with Refractory 0xide and

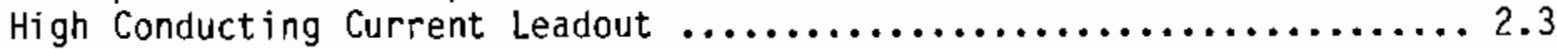

2 Proposed $\mathrm{HfO}_{2}-\mathrm{In}_{2} \mathrm{O}_{3}$ Phase Diagram at $1823 \mathrm{~K} \ldots \ldots \ldots \ldots \ldots \ldots \ldots \ldots \ldots \ldots$

3 Electrical Conductivities of $\mathrm{HfO}_{2}-\mathrm{RE}_{x} \mathrm{O}_{\mathrm{y}}$ Electrode Materials $\ldots \ldots \ldots .4$

4 Electrical Conductivity of $\mathrm{HfO}_{2}-\mathrm{In}_{2} \mathrm{O}_{3}, \mathrm{ZrO}_{2}\left(\mathrm{Y}_{2} \mathrm{O}_{3}\right)$

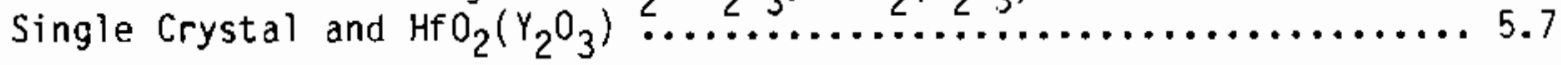

5 Electrical Conductivity - Activation Energy $\mathrm{HfO}_{2}-\operatorname{In}_{2} \mathrm{O}_{3} \ldots \ldots \ldots . \ldots . . .8$

6 Electrical Conductivity of Oxide Current Leadouts .............. 5.12

7 Electrical Conductivities of $\mathrm{HfO}_{2}-\operatorname{PrO}{ }_{1} 83^{-\mathrm{In}_{2} \mathrm{O}_{3}}$ at $923 \mathrm{~K}, 1273 \mathrm{~K}$,

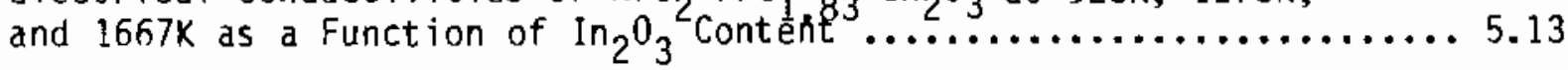

8 Electrical Conductivity of Current Leadout Materials ........... 5. 16

9 Electrical Conductivity of $(0.96-\dot{\chi}) \cdot\left[0.5 \mathrm{HfO}_{2} 0.5 \mathrm{PrO}_{2}\right] \cdot$

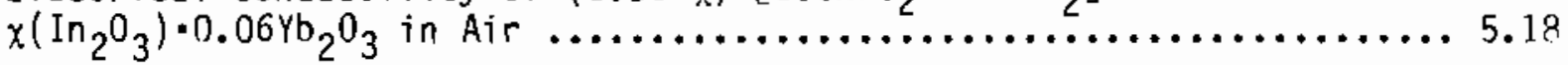

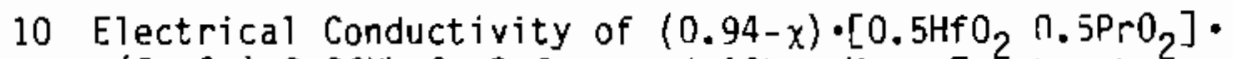
$\chi\left(\mathrm{In}_{2} \mathrm{O}_{3}\right) \cdot 0.06 \mathrm{Yb}_{2} \mathrm{O}_{3}$ Before and After Heat Treatment to

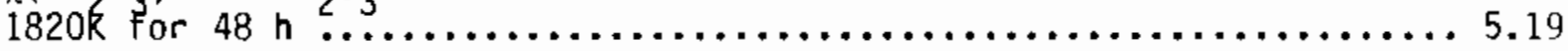

11 Phases at $1123 \mathrm{~K}$ in Air for $\mathrm{In}_{2} \mathrm{O}_{3}-\mathrm{SnO}_{2}$ as a Function of

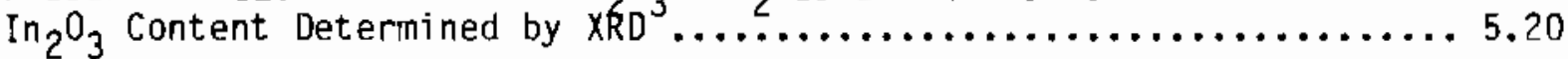

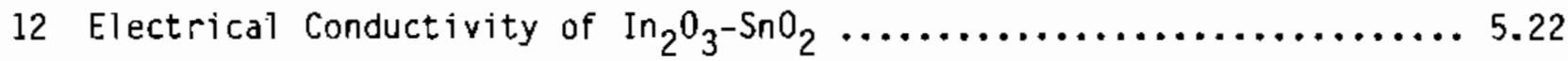

13 Electrical Conductivity of $\mathrm{In}_{2} \mathrm{O}_{3}-\mathrm{SnO}_{2}$ as a Function of $\mathrm{In}_{2} \mathrm{O}_{3}$ Concentration During Heating and Cooling $\ldots \ldots \ldots \ldots \ldots \ldots \ldots \ldots . \ldots \ldots$

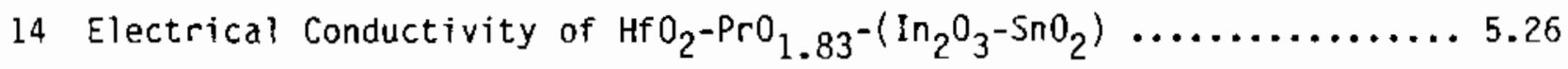

15 Cross Section of Electrode/Insulator and Water-Cooling Assembly ..... 6.3

16 Thermal Profile for MHD Test Electrode $\ldots \ldots \ldots \ldots \ldots \ldots \ldots \ldots \ldots \ldots \ldots$ 


\section{TABLES}

1 Fabrication Process and Properties of Ceramic Electrodes .......... 3.2

2 Composition and Density of $\mathrm{HfO}_{2}-\mathrm{RE}_{x} \mathrm{O}_{y}$ Electrode Materials $\ldots \ldots \ldots . .2$

3 Electrical Conductivity of $\mathrm{HfO}_{2}-\mathrm{RE}_{\mathrm{x}} \mathrm{O}_{\mathrm{y}}$ Electrode Materials $\ldots \ldots \ldots \ldots 5$

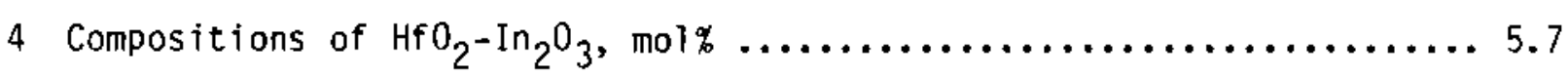

5 Compositions and Electrical Conductivity of $\mathrm{HfO}_{2}-\mathrm{In}_{2} \mathrm{O}_{3} \ldots \ldots \ldots \ldots . . . .9$

6 Composition and Density of 0xide Current Leadouts .............. 5.10

7 Electrical Conductivity of 0xide Current Leadouts $\ldots \ldots \ldots \ldots \ldots \ldots \ldots . \ldots 11$

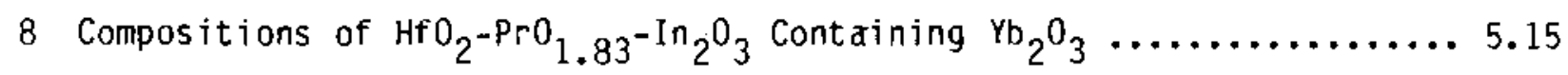

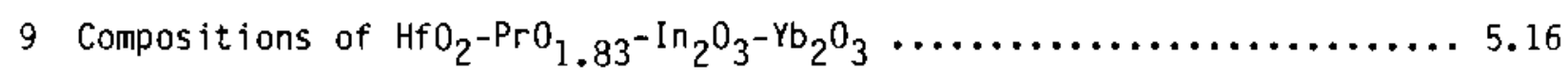

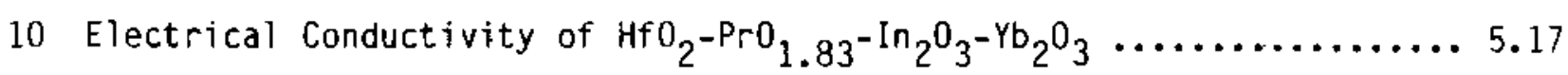

11 Electrical Conductivity values of $\mathrm{In}_{2} \mathrm{O}_{3}-\mathrm{SnO}_{2} \ldots \ldots \ldots \ldots \ldots \ldots \ldots \ldots . \ldots \ldots$

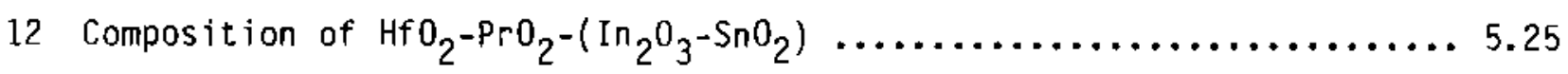

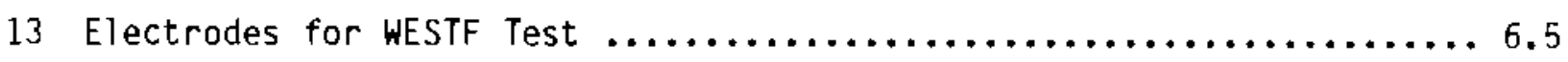


. . 


\subsection{INTRODUCTION}

Pacific Northwest Laboratory (PNL), (a) supported by the U.S. Department of Energy (DOE), is developing advanced materials for use in magnetohydrodynamics (MHD) power generation, an advanced energy conversion system in which the flow of an electrically conducting fluid interacts with a magnetic field to convert the energy directly into electricity. In a coal-fired, open-cycle MHD generator, the fluid is a hot combustion gas, seeded with potassium to make it electrically conducting (Bates 1969, 1978c). In the simplest MHD channel, the high-velocity gas at $2800 \mathrm{k}$ flows through a rectangular channel where it interacts with a perpendicular magnetic field to create a DC-current flux in the third orthogonal direction. The active elements of this MHD channel are the anode and cathode electrode walls, which transfer the electric current from the gas plasma to an external load.

For a Faraday or linear channel, the electrode wall consists of alternating slabs of electrodes and insulators over which the hot gas passes at velocities near the speed of sound. The electrodes may be "cold" metal that operates near 750K, or "hot" ceramics that operate above 1600K. In a clean fuel, such as natura? gas, the potassium may interact with the electrode/insulator materials, including condensation on the walls if a cold electrode is used. In coalfired systems, layers of coal slag containing potassium may also condense and interact with the channel wall if the electrode temperatures are lower than 1600K. In both electrode systems, the DC-current moves perpendicularly to the electrode wall, passing to and from the electrode/gas interface.

In cold channel walls in clean fuel, the current must pass through a cold, gas boundary layer. In coal-fired channels, the coal slag will condense on the cold electrode, and the current must pass through the slag layer, which also is a poor electrical conductor at low temperatures. Electrical transport across these insulating layers occurs by arcing or other current breakdown processes. This results in ohmic losses and current instabilities with energy loss.

(a) Operated for the DOE by Battelle Memorial Institute. 
The high electrode surface temperatures in ceramic electrode channels eliminate the cold gas or coal slag boundary layers so that the current can pass directly across the solid/gas interface free of the arcing and current instabilities that result in ohmic or breakdown losses. In addition, the low thermal conductivity of the ceramic reduces heat loss from the channel.

The hot, ceramic electrode, although both electrically and thermaliy attractive for MHD channel operation, must also be resistant to the hightemperature interactions between the high-velocity plasma, the coal slag, the potassium seed, and the high electrical DC-current densities (Bowen 1979; Bowen and Rossing 1976a,b). This places stringent requirements on the properties of the electrode materials. These electrodes must have: 1) electrical conductivities above 0.01 (ohm-cm) ${ }^{-1}$ from near room temperature to $1900 \mathrm{~K}, 2$ ) resistance to both electrochemical and chemical corrosion by both slag and potassium seed, $3)$ resistance to erosion by high-velocity gases and particles, 4) resistance to thermal shock, 5) adequate thermal conductivity, 6) compatibility with other channel components, particularly the electrical insulators, 7) oxidationreduction stability, and 8 ) adequate thermionic emission.

The MHD electrode ceranic materials for hot-walled channels are of two major classes. The first of these are electrically conducting ceramics that exhibit only small variations in electronic conduction with temperature and can conduct at room temperature (e.g., graphite, $\mathrm{ZrB}_{2}$, doped $\mathrm{LaCrO}_{3}$ ). These materials are generally not compatible with oxygen, combustion gases, and/or seed at high temperatures. The second class of materials are the more chemically resistant oxides, such as stabilized $\mathrm{ZrO}_{2}$. These have adequate electrical conductivity at temperatures above 1600K, but unacceptabty low electrical conductivity at lower temperatures. These lower electrical conductivities result in high Joule losses and thermal and electrochemical instabilities. In addition, the stabilized $\mathrm{ZrO}_{2}$ is an ionic conductor, and the current transferred to the cold metal conductor must involve an oxidation-reduction reaction. Large chemical gradients may occur as current densities increase, resulting in the potential for chemical degradation.

The purpose of the work described in this report was to develop hightemperature ceramic electrodes that meet the requirements described above, 
especially that of a hot, thermally and chemically stable surface adjacent to the hot plasma, adequate electric conduction at all temperatures, electrochemical stability in seed and coal $\mathrm{slag}$, and an electronically conducting, cold oxide surface that can be attached to the metal current connection. This report describes the concept of a high-temperature, graded ceramic composite electrode and the research directed toward its development. Although a channel was designed and constructed for testing this concept, the scope of the program did not accommodate testing the channel. Details of this research and development can be found in a series of reports, (a) publications, (b) and patents. (c)

\footnotetext{
(a) Bates 1975, 1976a through e, 1977a and b, 1978a and b; Bates and Marchant 1978a, 1979a through $c, 1982 a$ and b, 1983a through c; Bates, Griffin and Marchant 1981.

(b) Anderson et al. 1978; Bates 1977c; Bates and Garnier 1981; Bates and Marchant 1978; Bates and Mellinger 1975; Bates, Rossing and Bowen 1976; Cadoff et a1. 1978; Marchant and Bates 1980a and b; Marchant, Griffin and Bates 1978; Romanov et a1. 1976.

(c) Bates and Marchant 1980, 1981.
} 
.

.

.

$\checkmark$ 


\subsection{GRADED CERAMIC COMPOSITE ELECTRODE}

\subsection{BACKGROUND}

A high-temperature ceramic electrode was developed for hot-wall channels of open-cycle, coal-fired MHD power generation systems. This graded ceramic composite electrode was designed to operate at plasma/electrode surface temperatures above 1800k. These high plasma/electrode surface temperatures can improve channel performance and efficiency by: 1) eliminating the arcing between the plasma and the electrode surface, 2) reducing heat losses, and 3) eliminating or minimizing slag deposition on the electrode-insulator surfaces, thereby reducing the interactions of electrochemical corrosion. The high temperatures introduce a number of other electrode requirements that are not relevant to cold electrode systems. The major requirement is for refractory materials (oxides) that exhibit a high electrical conductivity, greater than $0.1(\text { ohm }-\mathrm{cm})^{-1}$, over the wide temperature range and large temperature gradients that exist from the hot ceramic electrode/plasma surface (>1800K) to the cold metal base $(<500 K)$. However, these high temperatures enhance the chemical and electrochemical reactions between the plasma, slag, insulators, and other materials and the ceramic electrode; the rates of these reactions increase significantly with temperature. Furthermore, ceramics generally exhibit poor thermomechanical resistance and the mismatch in thermal expansion makes it difficult to bond the ceramic electrode to the metal (Cu) base.

The graded ceramic composite electrode was being developed to address the problems described above. The criteria used in the development effort were that the electrode should be: 1) thermodynamically stable with a high melting point and low vapor pressure; 2) electrically conducting at room temperature and above; 3) electrochemically stable to potassium seed, coal slag and electrical insulators; and 4) easily fabricated with a graded composition.

The graded ceramic composite electrode concept consists of a refractory, thermally stable, electrically conducting oxide, such as cubic stabilized $\mathrm{HfO}_{2}$ or $2 \mathrm{rO}_{2}$, which can be exposed to the high-temperature plasma. This hightemperature, electrically conducting oxide (which does not exhibit high electrical conductivity at lower temperatures) is graded in chemical composition 
with other oxide additions into a low-temperature, electrically conducting oxide (which is generally less refractory at high temperatures) that can be attached to the cold metal base. This concept is shown schematically in Figure 1. The example in Figure 1 indicates three compositions; however, only two may be required and more than three could be advantageous. In addition, the gradations may be either as distinct steps or as continuous gradations in composition. As shown, the result is a composite electrode with high electrical conductivity over the large temperature gradient from the plasma surface to the metal base. Furthermore, the electrode surface is thermodynamically stable and corrosion resistant even at the high temperatures of the plasma.

\subsection{MATERIALS SELECTION}

Two critical areas were addressed in developing this ceramic electrode concept: 1) the refractory oxides, intermediate oxides, and low-temperature, electrically conducting oxides (designated as the oxide current leadout) must be structurally, thermomechanically, and electrochemically compatible with each other under MHD channel operating conditions; 2) the oxide current leadout must. be attached to the cold metal base to accommodate the thermomechanical stresses due to the expected mismatch in thermal expansion between the oxide and the metal. At the same time, this attachment must conduct both electricity and heat.

The materials selected for use in this electrode were centered around $\mathrm{HfO}_{2}$ stabilized into the face-centered-cubic ( $f(c)$, fluorite phase with $R_{x} 0_{y}$ $(R E=$ rare earth) as the high-temperature electrode composition. Using this same $\mathrm{HfO}_{2}-\mathrm{RE}_{x} \mathrm{O}_{y}$ base, other metal oxides were added to make the oxide electrically conducting at low temperatures while retaining its original thermal mechanical properties. The development was centered around $\mathrm{HfO}_{2}-\mathrm{RE}_{x} \mathrm{O}_{\mathrm{y}}-\mathrm{In}_{2} \mathrm{O}_{3}$ as the oxide current leadout composition. $\mathrm{HfO}_{2}$ was selected over $\mathrm{ZrO}_{2}$ because of its higher thermodynamic and chemical stability and because the monoclinic to tetragonal to cubic phase transition temperatures are 500 to $800 \mathrm{~K}$ higher for $\mathrm{HfO}_{2}$ than for $\mathrm{ZrO}_{2}$. The rare-earth-stabilized $\mathrm{HfO}_{2}$ had exhibited significant resistance to electrochemical corrosion in molten coal slags and alkali saits (Cadoff et al. 1978; Marchant and Bates 1980a and b; Marchant, Griffin and 


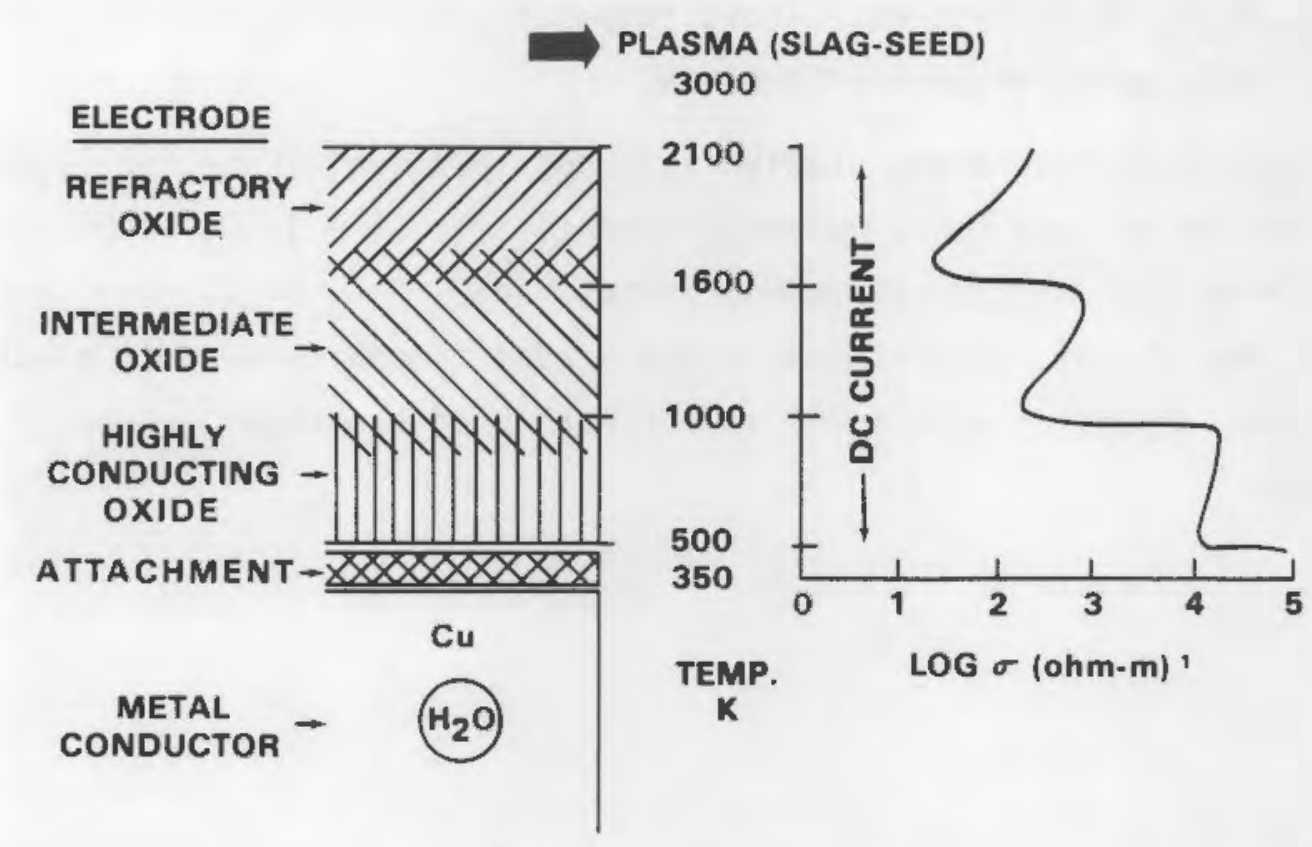

FIGURE 1. Concept of Graded Composite Electrode with Refractory 0xide and High Conducting Current Leadout

Bates 1978). Indium oxide has also demonstrated the ability to substantially increase the electrical conductivity of the rare-earth-stabilized $\mathrm{HfO}_{2}$ and to make the oxide electronically conducting with only small changes in the thermal expansion properties (Marchant and Bates 1980a and b; Marchant, Griffin and Bates 1978).

Preliminary studies were conducted on a number of other rare-earth and hafnium-oxide systems to determine which binary and ternary systems might exhibit the best electrochemical corrosion resistance with the potential for adequate electrical conductivity at low temperatures. This investigation included praseodymium, neodymium, samarium, europium, terbium, erbium, ytterbium, and yttrium oxides combined with hafnium oxide. In the range of 10 to $20 \mathrm{~mol} \%$ rare-earth of the stabilized $\mathrm{HfO}_{2}$, the electrochemical corrosion resistance, determined using a simple immersion method at $1675 \mathrm{~K}$ in molten "Rosebud" coal slag containing $5 \%$ potassium carbonate, showed the relative reactivity as oxide additions to be $\mathrm{Eu}>\mathrm{Sm}>\mathrm{Yb}>\mathrm{Pr}>\mathrm{Y}>\mathrm{Tb}$. All were more reactive than pure $\mathrm{HfO}_{2}$. Preliminary electrical conductivity studies using these same oxides showed that $\mathrm{Pr}$ and $\mathrm{Yb}$ oxide additions gave the highest electrical conduction in 
the $\mathrm{PrO}_{1.83^{-}} \mathrm{RE}_{\mathrm{x}} \mathrm{O}_{\mathrm{y}}-\mathrm{In}_{2} \mathrm{O}_{3}$ systems. Thus, research centered on the $\mathrm{HfO}_{2}-\mathrm{PrO}_{1.83^{-}}$ $\mathrm{In}_{2} \mathrm{O}_{3}$ with $\mathrm{Yb}_{2} \mathrm{O}_{3}$ added in smaller amounts.

The $\mathrm{In}_{2} \mathrm{O}_{3}-\mathrm{SnO}_{2}$ system was studied as a possible substitute for $\mathrm{In}_{2} \mathrm{O}_{3}$ to increase the thermal and electrochemical stability of the $\mathrm{In}_{2} \mathrm{O}_{3}$-stabilized $\mathrm{HfO}_{2}$ while retaining high electronic conductivity. $\mathrm{In}_{2} \mathrm{O}_{3}-\mathrm{SnO}_{2}$ might also have been selected as one of the compositions in the graded composite ceramic electrode if the thermal expansion were found to match that of the other graded compositions. 


\subsection{FABRICATION}

Methods for synthesizing and processing the $\mathrm{Hf}_{2}-\mathrm{RE}_{x} \mathrm{O}_{y}-\mathrm{In}_{2} \mathrm{O}_{3}$ were developed to fabricate samples for physical property, phase equilibria, and electrochemical studies and for MHD electrode testing. Ceramic bodies with reproducible properties, controlled density, and similar structures were required. Because these materials were not available commercially and the techniques for synthesizing and processing the ceramic powders into ceramic shapes were not available, it was necessary to develop methods for fabricating powders from starting materials and for sintering them into compacts. In addition, the sintering rates for the different oxides must be the same to fabricate the different compositions into an integral electrode during the same sintering process.

Simple techniques of mixing, pressing, and sintering the individual oxides were not successful and resulted in low-density, multiphase compacts, and reproducibility was difficult. Some high-density, single-phase compositions could be prepared by sintering above 2150K; however, it was necessary to lower the sintering temperatures below $1875 \mathrm{~K}$ so that the lower-temperature, hafniumbase current leadout materials containing $\mathrm{In}_{2} \mathrm{O}_{3}$ could be prepared with, and as an integral part of, the highly refractory oxide.

A coprecipitation synthesis process was developed for fabricating $\mathrm{HfO}_{2}$ $\mathrm{RE}_{x} \mathrm{O}_{y}$ and $\mathrm{HfO}_{2}-\mathrm{RE}_{x} \mathrm{O}_{y}-\mathrm{In}_{2} \mathrm{O}_{3}$ with reproducible, high-density sintered bodies having uniform microstructures and properties. The technique was flexible, in that a wide selection of $\mathrm{HfO}_{2}-\mathrm{RE}_{x} \mathrm{O}_{y}-\mathrm{In}_{2} \mathrm{O}_{3}$ compositions could be prepared by this technique. The technique involved the dissolution of rare-earth oxide powder in nitric acid (although some rare earths could be purchased in nitrate form). These salt solutions were then mixed with hafnium salts (oxychloride, nitrates, or sulfates) and indium salt solutions, coprecipitated with ammonium hydroxide, filtered, washed, and dried. The precipitate was calcined to form the oxide. These powders were comminuted, cold pressed, and sintered. The typical process for fabricating these $\mathrm{HfO}_{2}-\mathrm{RE}_{x} \mathrm{O}_{y}-\mathrm{In}_{2} \mathrm{O}_{3}$ compositions into highquality, sintered compacts is outlined in the flowsheet in Table 1; the various steps are described in more detail in the paragraphs that follow. 
TABLE 1. Fabrication Process and Properties of Ceramic Electrodes

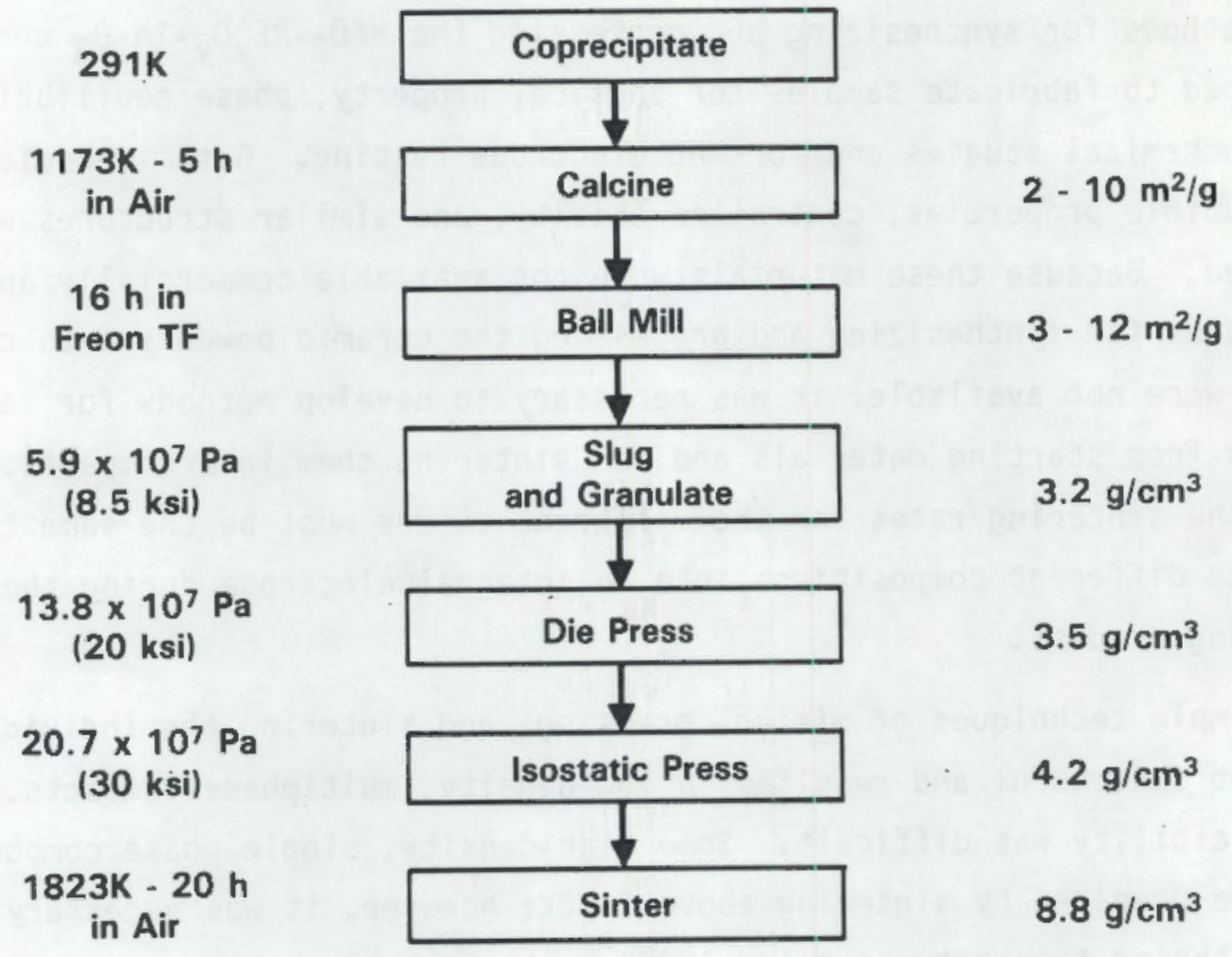

Coprecipitation. The rare-earth-oxide powders were dissolved in concentrated nitric acid; the hafnium oxychloride, in water. 'The solutions were diluted and mixed and the mixed oxide powders were coprecipitated from the solution by using an ammonium hydroxide solution. The precipitate was filtered and washed sequentially with water, acetone, toluene, and again acetone before air drying. The resultant granular powder was a hydroxide salt that was calcined in air for four hours between 1073K and 1273K. X-ray diffraction (XRD) analyses of the post-calcined powders show that, for most compositions, the rare-earth stabilization of the hafnium powders occurred during calcination and resulted in the fluorite, pyrochlore, and monoclinic phases as predicted from the phase diagram.

Ball Milling. The powders were ball milled to break up the agglomerates that formed during calcination before pressing and sintering. Ball milling was performed in a Neoprene-lined mill with $\mathrm{CaO}$-stabilized $\mathrm{ZrO}_{2}$ grinding balls in a Freon TF wet grinding medium. The ball milling increased the surface area. 


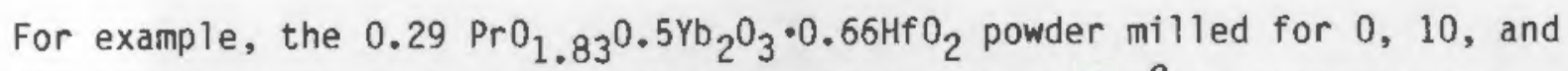
960 minutes had surface areas of $12.4,14.4$, and $16.1 \mathrm{~m}^{2} / 9$, respectively. Ball milling also improved the flow properties of the powders and the uniformity of the sintered material.

Pressing. The powders were slugged at $69 \mathrm{MPa}(10,000 \mathrm{psi})$ before passing through a -145 Tyler mesh screen. The slugged and granulated powder was pressed uniaxially in steel dies at $152 \mathrm{MPa}(22,000 \mathrm{psi})$ into right parallelepipeds. For graded compositions, the high-temperature electrode composition (e.g., the stabilized $\mathrm{HfO}_{2}$ ) was placed in the steel die and very lightly pressed to form a smooth surface; a uniform layer of the lower-temperature, electronically conducting oxide was then added and again lightly pressed in the die. Another uniform layer of the stabilized $\mathrm{HfO}_{2}$ was added and pressed at high pressure. Humidity from the air provided an adequate binder. For final compaction, the green bars were isostatically pressed in double-rubber ( $p l a s-$ tic) evacuated containers in a water-soluble oil at $228 \mathrm{MPa}(33,000 \mathrm{psi})$.

Sintering. The bars or cylinders were sintered between $1850 \mathrm{~K}$ and $1875 \mathrm{~K}$ in air. Sintering times varied from 8 to 20 hours, with 5-hour heatup and cooldown cycles. Sintering times and temperatures were selected according to the desired final density, powder characteristics and oxide compositions. Each bar or cylinder was then sectioned near the center to produce two electrodes. This multiple fabrication method was employed to eliminate fracture and bending of the bar during sintering due to slight mismatches in sintering rates between the two materials.

Since an integral electrode composed of more than one ceramic material was required for the graded ceramic composite electrode, it was necessary to prepare powders of the various compositions that could be sintered simultaneously into a single electrode bar. By controlling the coprecipitation, calcination, and ball milling, the sintering rates of the various oxides could be controlled. The powders of both the refractory oxide and the low-temperature, electrically conducting oxide were activated and deactivated by altering the calcining conditions. This provided approximately the same sintering rates and shrinkage during sintering so that the compact would not fracture during sintering and intimate contact could be obtained between the different ceramic materials. 



\subsection{PHASE EQUILIBRIA}

A ternary phase diagram was developed for the $\mathrm{HfO}_{2}-\mathrm{PrO}{ }_{1.83}-\mathrm{In}_{2} \mathrm{O}_{3}$ system at $1823 \mathrm{~K}$ in air to identify structures that might provide the highest electrical conductivity, best electrochemical corrosion resistance in molten coal slag and potassium seed, good thermal stability, and compatibility with stabilized $\mathrm{HfO}_{2}$. The diagram was developed with air-cooled samples using quantitative energydispersive $x$-ray analysis (EDAX) to identify the phase compositions and XRD to determine the crystallographic structures. The binary phase relationships were determined for the $\mathrm{HfO}_{2}-\mathrm{In}_{2} \mathrm{O}_{3}$ and $\mathrm{PrO}_{1.83}-\mathrm{In}_{2} \mathrm{O}_{3}$ systems; the $\mathrm{HfO}_{2}-\mathrm{PrO}_{1.83}$ had been determined previously (Kravchinskaya et al. 1973). The structures and compositions of samples inside the ternary were coupled with these binary-phase diagram data to generate the ternary diagram shown in Figure 2.

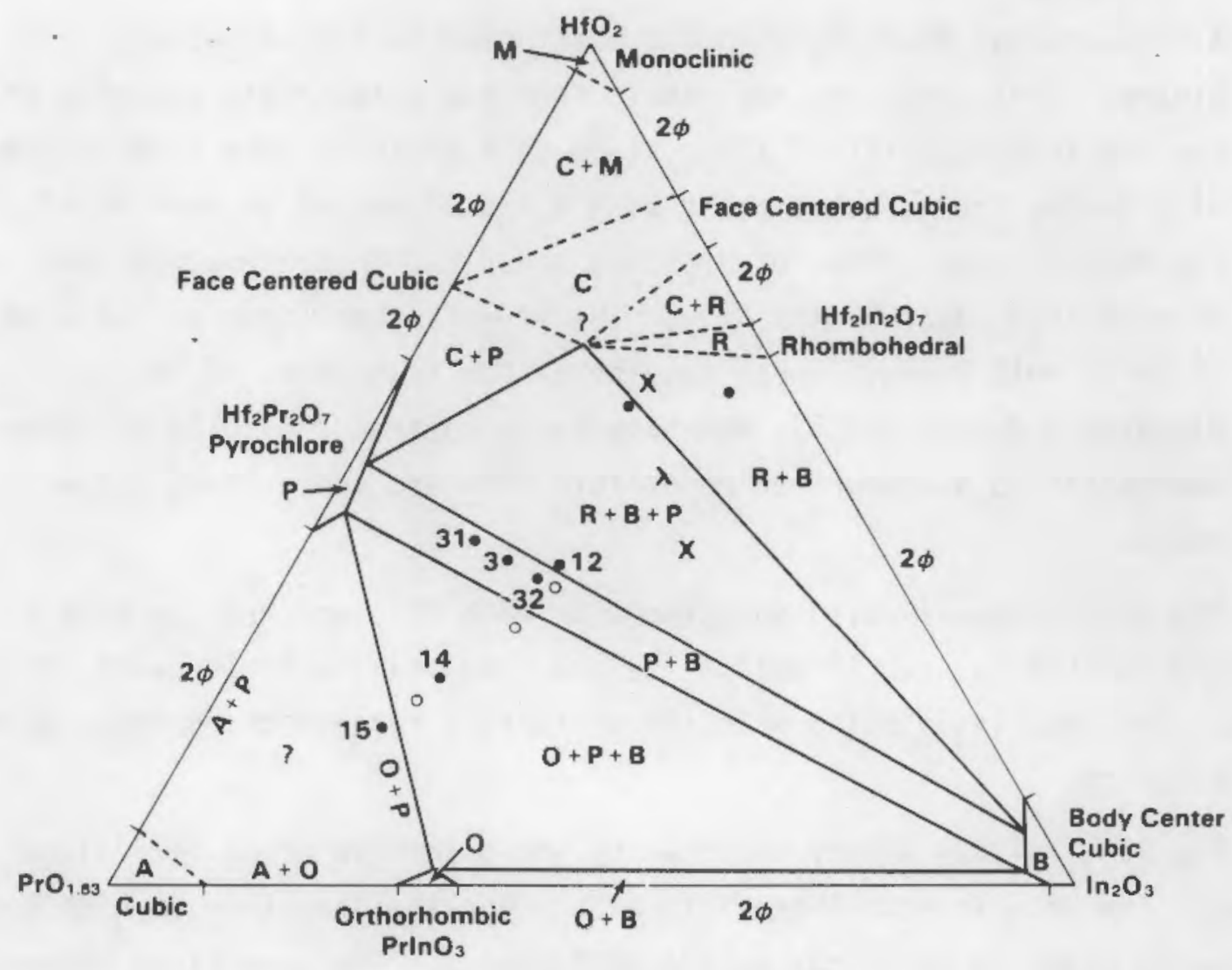

FIGURE 2. Proposed $\mathrm{HfO}_{2}-\mathrm{In}_{2} \mathrm{O}_{3}$ Phase Diagram at $1823 \mathrm{~K}$ 
The $\mathrm{HfO}_{2}-\mathrm{PrO}_{1} .83^{-\mathrm{In}_{2} \mathrm{O}_{3}}$ phase diagram revealed characteristics significant to the development of the current leadouts for the graded ceramic composite electrode. Two new phases were identified:

- An orthorhombic $\mathrm{PrInO}_{3}$ phase was found in the $\mathrm{PrO}_{2}-\mathrm{In}_{2} \mathrm{O}_{3}$ binary. This orthorhombic phase (with lattice parameters of a, b, $c=0.567$, $0.593,0.818 \mathrm{~nm}$, respectively) has solubility limits from 30 to $36 \mathrm{~mol} \% \mathrm{In}_{2} \mathrm{O}_{3}$. The higher indium solubility is found at the phase boundary next to the two-phase region consisting of the orthorhombic $\mathrm{PrInO}_{3}$ and body-centered-cubic (bcc) $\mathrm{In}_{2} \mathrm{O}_{3}$ solid solution. The solubility limit of $\mathrm{PrO}_{1.83}$ in the solid solution is about $2 \mathrm{~mol} \%$. The solubility of $\mathrm{In}_{2} \mathrm{O}_{3}$ in $\mathrm{PrO}_{1.83}$ is between 7 and $10 \mathrm{~mol} \%$ with a lattice parameter of $0.546 \mathrm{~nm}$ at maximum solubility compared to $54.7 \mathrm{~nm}$ for $\operatorname{PrO}_{1.83}$.

- A rhombohedral $\mathrm{Hf}_{2} \mathrm{Pr}_{2} \mathrm{O}_{7}$ compound was formed in the $\mathrm{HfO}_{2}-\mathrm{In}_{2} \mathrm{O}_{3}$ binary. This structure may result from the anisotropic ordering of the fcc $\mathrm{In}_{2} \mathrm{O}_{3}$-stabilized $\mathrm{ZrO}_{2}$, since this phase is only a few tenths of a degree from a cubic phase with $a=2.35 \mathrm{~nm}$ and alpha $=90.4^{\circ}$. The nominal composition of $\mathrm{Hf}_{2} \mathrm{In}_{2} \mathrm{O}_{7}$ under microprobe analysis was $35 \mathrm{~mol} \% \mathrm{In}_{2} \mathrm{O}_{3}$ and $65 \mathrm{~mol}_{\%} \mathrm{HfO}_{2}$. The $\mathrm{HfO}_{2}$ is stabilized as fcc with 10 to $24 \mathrm{~mol}_{2} \mathrm{In}_{2} \mathrm{O}_{3}$. These results differ from those of Saito, Maruyama and Kato (1983), who have reported that the solid solution decomposes to a mixture of monoclinic $\mathrm{HfO}_{2}$ and cubic $\mathrm{In}_{2} \mathrm{O}_{3}$ below 1623K.

The $\mathrm{In}_{2} \mathrm{O}_{3}$ forms a solid solution with both $\mathrm{HfO}_{2}$ and $\mathrm{PrO}_{1.83}$ with a combined solubility near $10 \mathrm{~mol} \%$. The exact solubility limits were not determined. This bcc $\operatorname{In}_{2} \mathrm{O}_{3}$ solid solution exhibits a rare-earth, B-type, sesquioxide structure.

The $\mathrm{PrO}_{1.83}-\mathrm{HfO}_{2}$ binary reported by Kravchinskaya et al. (1973) was confirmed. The $\mathrm{HfO}_{2}$ is stabilized into a fcc fluorite structure at high temperature up to about $36 \mathrm{~mol}_{\%} \mathrm{PrO}_{1.83}\left(24 \mathrm{~mol}_{\%} \mathrm{Pr}_{2} \mathrm{O}_{3}\right.$ ). The pyrochlore compound $\mathrm{Hf}_{2} \mathrm{Pr}_{2} \mathrm{O}_{7}$ lies within the 1 imits of 42 to $57 \mathrm{~mol} \% \mathrm{Pr}_{1}{ }_{1.83}$. The reported lattice parameter of the $\mathrm{Hf}_{2} \mathrm{Pr}_{2} \mathrm{O}_{7}$ phase is $1.0662 \mathrm{~nm}$. 
The major portion in the center of the phase diagram most important to the high-electrical conducting oxides is made up of a phase field containing two or three phases of the structures detailed above. Using the above binary systems coupled with the examinations of ternary compositions with XRD and EDAX, a preliminary $\mathrm{HfO}_{2}-\mathrm{PrO}_{1.83^{-}} \mathrm{In}_{2} \mathrm{O}_{3}$ ternary phase diagram was developed. The ternary compositions were concentrated between the compositions between $\mathrm{Hf}_{2} \mathrm{Pr}_{2} \mathrm{O}_{7}$; $\mathrm{Hf}_{2} \mathrm{In}_{2} \mathrm{O}_{7}$, and the $\mathrm{In}_{2} \mathrm{O}_{3}$-stabilized $\mathrm{HfO}_{2}$. Two large three-phase regions were identified: the orthorhombic, pyrochlore, and bcc solid solution and the pyrochlore, rhombohedral, and bcc solid solution. Two significant two-phase regions of pyrochlore/bcc solid solution and rhombohedral/bcc solid solution were also found in the phase diagram. Regions high in $\mathrm{PrO}_{1.83}$ and $\mathrm{HfO}_{2}$ remain to be defined. However, the results suggest that a compound may exist near $0.65 \mathrm{HfO}_{2} \cdot 0.18 \mathrm{PrO}_{1.83^{\circ}} 0.17 \mathrm{In}_{2} \mathrm{O}_{3}$. As will be discussed later, the highest electrical conduction is associated with these two- and three-phase compositions, while the highest corrosion resistance is associated with the phase highest in $\mathrm{HfO}_{2}$. The phase field is not complete, but it provided the direction for developing electronically conducting current leadout materials. 



\subsection{ELECTRICAL CONOUCTIVITY}

An understanding of the electrical conductivity of the oxides is critical for selecting compositions, improving properties and structures and evaluating the performance of materials for use in the graded ceramic composite electrode. Electrical conductivities were determined in air as a function of temperature to identify the compositions, structures and phases relating to the phase diagram and to high electrical (electronic) conductivities.

Initial electrical conductivity studies were given to those $\mathrm{HfO}_{2}$ rareearth oxide systems that would provide the highest electrical conductivity and the best electrochemical corrosion resistance to molten coal slag containing potassium seed. Those systems with the highest potential were evaluated further; additions of $\mathrm{In}_{2} \mathrm{O}_{3}$ were made to increase the low-temperature electrical conductivity. The $\mathrm{HfO}_{2}-\mathrm{In}_{2} \mathrm{O}_{3}$ systems with $\mathrm{PrO}_{1.83}, \mathrm{Y}_{2} \mathrm{O}_{3}$, and $\mathrm{Yb}_{2} \mathrm{O}_{3}$ additions were selected for further studies of phase equilibria and electrical conductivity. The $\mathrm{HfO}_{2}-\mathrm{PrO}_{1.83}-\mathrm{In}_{2} \mathrm{O}_{3}$ system was eventually selected for the most indepth research and development.

\section{$5.1 \mathrm{Hf} 0_{2}-\mathrm{RE}_{\mathrm{x}}-\mathrm{O}_{\mathrm{y}}$}

The rare-earth stabilized hafnium oxides have demonstrated electrochemical stability in the potassium seed and coal slag environments (Marchant and Bates 1980a) and also are a critical part of the hot, graded composite ceramic MHD electrode. The selection of compositions for electrical conductivity studies was based upon electrochemical stability, fabricability, and rare-earth oxide additives that were thought to provide the highest electrical conductivities. Since only limited phase data have been reported for the $\mathrm{HfO}_{2}-\mathrm{RE}_{\mathrm{x}} \mathrm{O}_{\mathrm{y}}$ systems, potential compositions and structures were of ten based on the better known and analogous $\mathrm{ZrO}_{2}-\mathrm{RE}_{\mathrm{x}} \mathrm{O}_{\mathrm{y}}$ systems.

A four-contact technique was used to measure the electrical conductivity in air from 544 to $1704 \mathrm{~K}$. The oxide samples were prepared from coprecipitated powders which had been calcined at 1275K and ball milled to break agglomerates. The powders were uniaxially pressed followed by isostatic pressing. The samples were sintered in two ways: 1) in $2.67 \times 10^{-2} \mathrm{~Pa}\left(2 \times 10^{-4}\right.$ torr $)$ vacuum 
at 2225 to $2275 \mathrm{~K}$ for 4 to 5 hours followed by an air anneal at $1475 \mathrm{~K}$ for 8 hours, or 2) in air at $1825 \mathrm{~K}$ for 20 hours. The microstructures for all compositions (Table 2) were similar, with small, 1- to 2- m closed pores. Sample D had larger, irregularly shaped pores with a second phase present. Samples $Q$ and 0 contained microcracks after measurements were completed. All others were single phase.

TABLE 2. Composition and Density of $\mathrm{HfO}_{2}-\mathrm{RE}_{x} \mathrm{O}_{y}$ Electrode Materials

\begin{tabular}{|c|c|c|c|c|c|c|c|c|c|}
\hline \multirow{2}{*}{\multicolumn{2}{|c|}{ Electrode }} & \multicolumn{7}{|c|}{ Composition, mol\% } & \multirow{3}{*}{$\begin{array}{c}\begin{array}{c}\text { Density } \\
\mathrm{g} / \mathrm{cm}^{3}\end{array} \\
8.44\end{array}$} \\
\hline & & $\mathrm{HfO}_{2}$ & $\mathrm{Er}_{2} \mathrm{O}_{3}$ & $\operatorname{PrO}_{1.83}$ & $\mathrm{~Tb}_{4} \mathrm{O}_{7}$ & $\mathrm{Y}_{2} \mathrm{O}_{3}$ & $\mathrm{Yb}_{2} \mathrm{O}_{3}$ & $\mathrm{CeO}_{2}$ & \\
\hline 0 & $a, b$ & 91.4 & & 8.6 & & & & & \\
\hline Q & $a, b$ & 80 & & 20 & & & & & 8.94 \\
\hline$A-17$ & $a, b$ & 66 & & 29 & & & 5 & & 8.80 \\
\hline$A-273-1$ & $c$ & 66 & & 29 & & & 5 & & 8.34 \\
\hline$A-273-2$ & $c$ & 66 & & 29 & & & 5 & & 8.39 \\
\hline $\mathrm{F}$ & $a, b$ & 77.6 & & 17.5 & & & 2.9 & & 8.54 \\
\hline V & $a, b$ & 89.5 & & 5.3 & & & 9.2 & & 9.14 \\
\hline $120-3$ & $\mathrm{c}$ & 80 & 10 & 10 & & & & & 8.59 \\
\hline$C-4$ & $a, b$ & 80 & 10 & & 10 & & & & 8.36 \\
\hline $100-2$ & $c$ & 90 & & & 10 & & & & 7.02 \\
\hline $101-2$ & $c$ & 85 & & 5 & 5 & & 5 & & 6.73 \\
\hline$P$ & $a, b$ & 94.5 & & & 5.5 & & & & 8.05 \\
\hline$P-202$ & $a, b$ & 94.5 & & & 5.5 & & & & 8.37 \\
\hline$B-1$ & $a, b$ & 88 & & & 6 & 6 & & & 8.97 \\
\hline$B-273-1$ & $c$ & 88 & & & 6 & 6 & & & 8.13 \\
\hline$R$ & $a, b$ & 80 & & & & 20 & & & 6.24 \\
\hline I & $a, b$ & 82 & & & & 8 & & 10 & 7.93 \\
\hline B & $a$ & 89 & & & & & 11 & & 9.43 \\
\hline$D$ & $a, b$ & 80 & & & & & 20 & & 7.43 \\
\hline
\end{tabular}

(a) Sintered in $2.67 \times 10^{-2}$ Pa vacuum at 2225 to $2275 \mathrm{~K}$ for 4 to 5 hours.

(b) Annealed in air between 1375 and $1475 \mathrm{~K}$ for 8 hours.

(c) Sintered in air at 1875 to $1925 \mathrm{~K}$ for 20 hours. 
The electrical conductivities for most compositions could be represented by one or two straight $\left(\log _{10} \sigma\right.$ versus $\left.\mathrm{K}^{-1}\right)$ lines, one for the high-temperature and one for the low-temperature data (see Figure 3 and Table 3 ). The break in the curves generally occurred below 1000K. Some data exhibited a change in slope at lower temperatures, but it was either nonreproducible or could not be resolved into two linear relationships. The data for D, R, P, 100-2 did not exhibit breaks in the $\log _{10} \sigma$ versus $\mathrm{K}^{-1}$ curves even though measurements were made to temperatures as low as $625 \mathrm{~K}$. However, these oxides were approaching the lower conductivity value limit, which can be measured using the fourcontact technique.

Two oxides, $Q$ and $V$, exhibited a reproducible decrease in electrical conductivity above $\sim 1620 \mathrm{~K}$. The cause of this decrease was not known. The lowest conductivity values for 0 and $Q$ could possibly be attributed to sample cracking during the electrical conductivity measurements.

The activation energies for the high-temperature and low-temperature conductivities varied between 0.85 and $1.38 \mathrm{eV}$ and 0.24 and $0.98 \mathrm{eV}$, respectively. Some compositional factors appear to have influenced the hightemperature activation energy. Generally, the results suggest that an increase in $\mathrm{HfO}_{2}$ content and a decrease in $\mathrm{PrO}_{1.83}$ content result in an increase in the activation energy. Those samples, A-17, A-273-1, and A-272-2, that had high $\mathrm{PrO}_{1.83}$ concentrations exhibited higher high-temperature activation energies that that expected simply by reducing the $\mathrm{HfO}_{2}$ concentration. There appears to have been a slight increase in activation energy with decreasing $\mathrm{Yb}_{2} \mathrm{O}_{3}$. No patterns could be resolved for the effects of $\mathrm{Tb}_{4} \mathrm{O}_{2}, \mathrm{Er}_{2} \mathrm{P}_{3}$, or $\mathrm{Y}_{2} \mathrm{O}_{3}$. Those high-HfO $\mathrm{H}_{2}$ oxides without $\mathrm{PrO}_{1.83}(\mathrm{~B}, \mathrm{P}-202, \mathrm{P}$, and I) exhibited the lowest activation energies $(0.83$ to $0.86 \mathrm{eV})$.

A comparison of the magnitudes of the conductivities at 1000K suggests that the conductivity increases with increasing $\mathrm{HfO}_{2}$ content above $80 \mathrm{~mol} \%$, increases with increasing $\mathrm{Yb}_{2} \mathrm{O}_{3}$ content, and decreases slightly with increasing $\mathrm{Y}_{2} \mathrm{O}_{3}$ and $\mathrm{PrO}_{1.83}$ content. The effects of $\mathrm{Tb}_{4} \mathrm{O}_{7}$ and $\mathrm{Er}_{2} \mathrm{O}_{3}$ could not be defined with any certainty.

The electrical conductivities of 0.028 and 0.0043 (ohm-cm) $)^{-1}$ and activation energies of 1.12 and $1.4 \mathrm{eV}$ for these rare-earth stabilized $\mathrm{HfO}_{2}$ oxides 


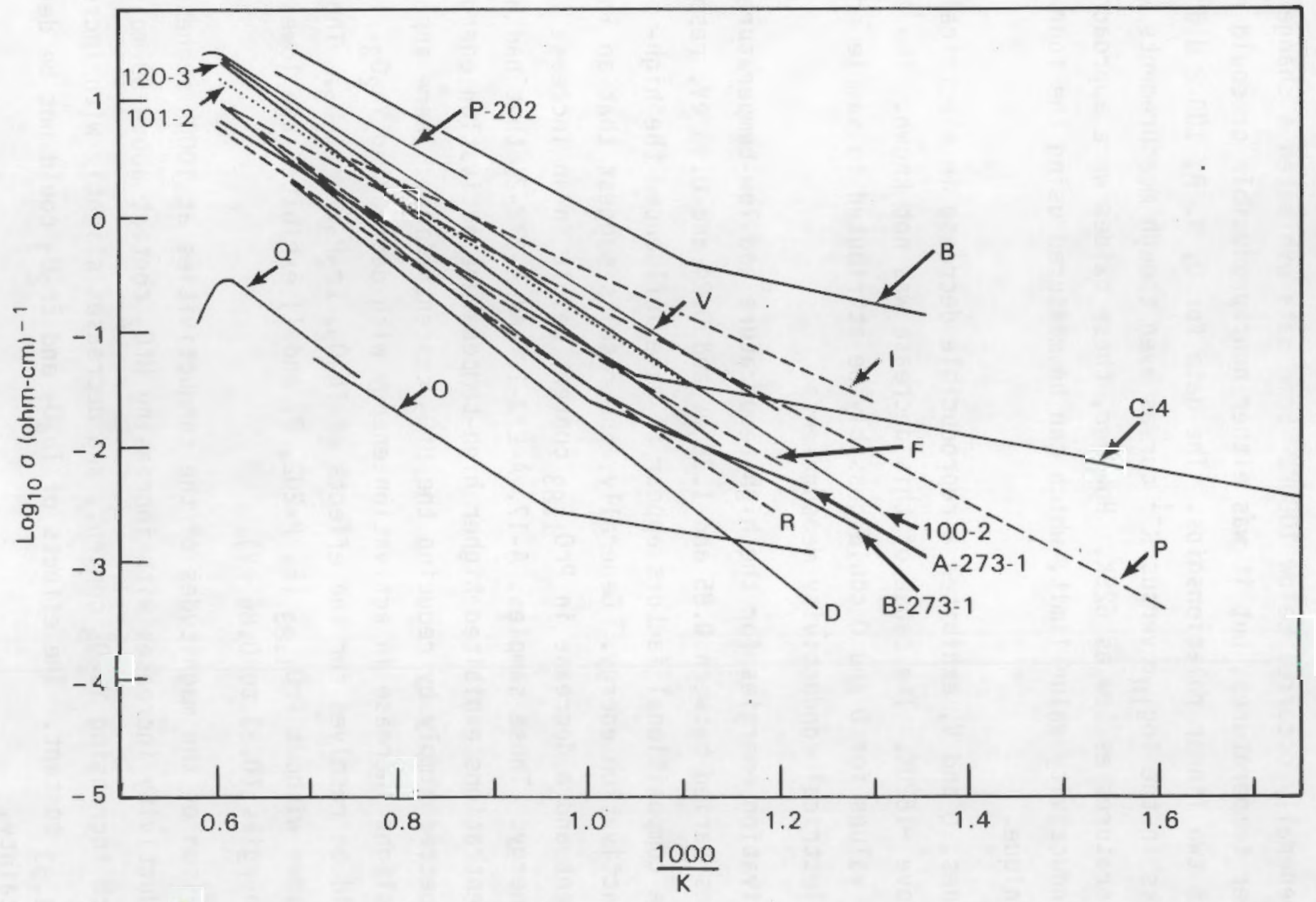

FIGURE 3. Electrical Conductivities of $\mathrm{HfO}_{2}-\mathrm{RE}_{x} \mathrm{O}_{y}$ Electrode Materials 
TABLE 3. Electrical Conductivity of $\mathrm{HfO}_{2}-\mathrm{RE}_{x} \mathrm{O}_{y}$ Electrode Materials

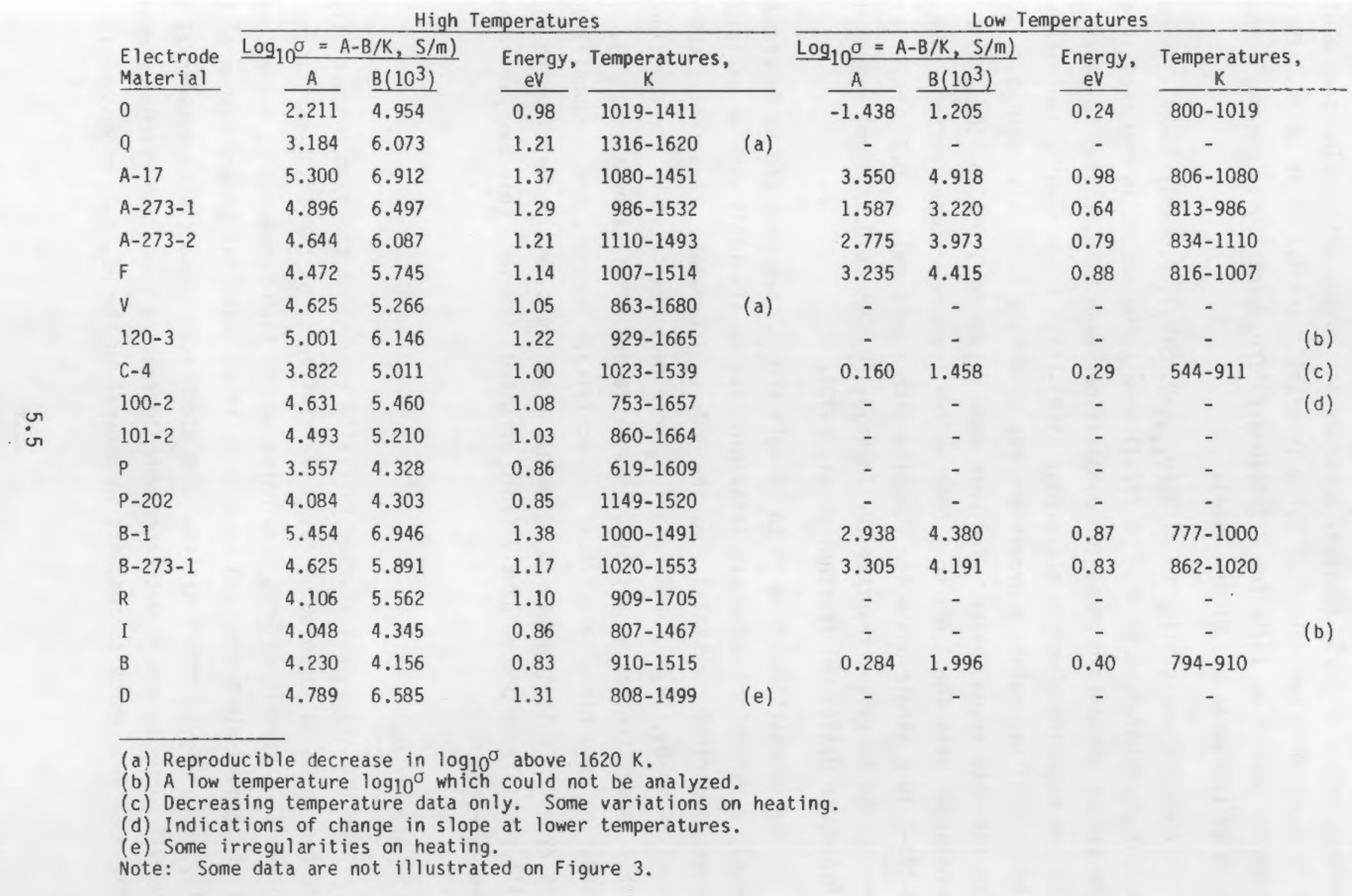


were very near the reported values for $0.08 \mathrm{Y}_{2} \mathrm{O}_{3} \cdot 0.92 \mathrm{HfO}_{2}$ and $0.20 \mathrm{Y}_{2} \mathrm{O}_{3}-0.80 \mathrm{HfO}_{2}$, respectively, at $1275 \mathrm{~K}$ (Besson, Deportes and Robert 1966). The sample of $0.2 \mathrm{Y}_{2} \mathrm{O}_{3} \cdot 0.8 \mathrm{HfO}_{2}$ had values of $0.006(\mathrm{ohm}-\mathrm{cm})^{-1}$ and $1.1 \mathrm{eV}$ at $1275 \mathrm{~K}$. The reported values at $1275 \mathrm{~K}$ for $0.125 \mathrm{Ca} 0 \cdot 0.875 \mathrm{ZrD}_{2}$ were $0.005(\mathrm{ohm}-\mathrm{cm})^{-1}$ and $1.83 \mathrm{eV}$ (Johansen and Cleary 1964).

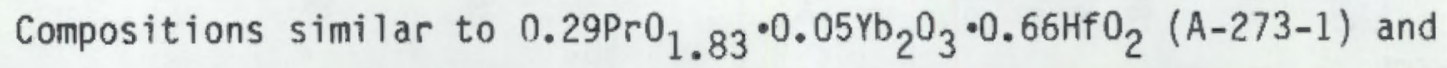
$0.06 \mathrm{~Tb}_{4} \mathrm{O}_{7} \cdot 0.06 \mathrm{Y}_{2} \mathrm{O}_{3} \cdot 0.88 \mathrm{HfO}_{2}(\mathrm{~B}-272-1)$ were to be tested in MHD facilities. The phases present in these two compositions have been studied in detail using XRD and scanning electron microscopy (SEM)-EDX. These results indicate that the A-273-1 was mainly a pyrochlore fcc structure (possibly $\mathrm{Pr}_{2} \mathrm{Hf}_{2}{ }_{7}$ ) with a $\mathrm{fcc}$ fluorite second phase. The unit cell values of $1.032 \mathrm{~nm}(10.32 \mathrm{~A})$ were consistent with the 1.061 to $1.0068 \mathrm{~nm}$ for low-temperature reacted $\mathrm{Pr}_{2} \mathrm{Hf}_{2}{ }_{7}$. B-273-1 is a single-phase fcc fluorite with a unit cell of $0.517 \mathrm{~nm}$. This is very close to values reported for $\mathrm{Tb}_{2} \mathrm{Hf}_{2}{ }^{0} 7(0.5205$ to $0.5216 \mathrm{~nm})$ and $\mathrm{Yb}_{2} \mathrm{Hf}_{2} \mathrm{O}_{7}$ (0.5141 to $0.5143 \mathrm{~nm}$ ) (Portnoi et al. 1970).

The compositions from 29 to $39 \mathrm{~mol} \% \mathrm{Pr}_{1.83}$ are expected to be predominantly a pyrochlore structure (Kravchinskaya et al. 1973) with an anticipated lower electrical conductivity as the $\mathrm{Pr}_{1}{ }_{1.83}$ increases. Conversely, the additions of $\mathrm{Er}_{2} \mathrm{O}_{3}, \mathrm{~Tb}_{4} \mathrm{O}_{7}, \mathrm{Yb}_{2} \mathrm{O}_{3}$ and $\mathrm{Y}_{2} \mathrm{O}_{3}$ were reported to stabilize the fluorite cubic phase (Portnoi et al. 1970; Glushkova and Krzhizkanovskaya 1973), resulting in a higher electrical conductivity. However, the conductivity of the pyrochlore is expected to be mainly electronic, while the fluorite phases will possibly be predominantly ionic or mixed; however, this has yet to be demonstrated.

\section{$5.2 \mathrm{HfO}_{2}-\mathrm{In}_{2} \mathrm{O}_{3}$}

The $\mathrm{HfO}_{2}-\mathrm{In}_{2} \mathrm{O}_{3}$ was studied initially because of the high conductivity of the bcc $\mathrm{In}_{2} \mathrm{O}_{3}$ solid solution (ss), the similarity of the $\mathrm{In}_{2} \mathrm{O}_{3}$-stabilized $\mathrm{HfO}_{2}$ to the $\mathrm{Y}_{2} \mathrm{O}_{3}$-stabilized $\mathrm{HfO}_{2}$ considered as the high-temperature, refractory cap of the graded electrode, and because it is an essential binary system of the $\mathrm{HfO}_{2}-\mathrm{RE}_{x} \mathrm{O}_{y}-\mathrm{In}_{2} \mathrm{O}_{3}$ ternary system. The electrical conductivity between 17 and $40 \mathrm{~mol} \% \mathrm{In}_{2} \mathrm{O}_{3}$ (Table 4 ) decreased with increasing $\mathrm{In}_{2} \mathrm{O}_{3}$ and reached a minimum near near $40 \%$, which corresponds in general to the $\mathrm{Hf}_{2} \mathrm{In}_{2} \mathrm{O}_{7}$ rhombohedral 
TABLE 4. Compositions of $\mathrm{HfO}_{2}-\mathrm{In}_{2} \mathrm{O}_{3}, \mathrm{~mol} \%$

\begin{tabular}{|c|c|c|}
\hline Sample3 & $\mathrm{HfO}_{2}$ & $\mathrm{In}_{2} \mathrm{O}_{3}$ \\
\hline FC $-13-3$ & 0 & 100 \\
\hline FC -53 & 69 & 31 \\
\hline FC-14-1 & 60 & 40 \\
\hline$F C-52$ & 50 & 50 \\
\hline FC $-54-1$ & 83 & 17 \\
\hline
\end{tabular}

composition (Figures 4 and 5 and Table 5). The conductivity then increased rapidly between 40 and $50 \mathrm{~mol} \%$, which is attributed to the increasing presence of the bcc $\mathrm{In}_{2} \mathrm{O}_{3}$ (s5) phase. The conductivity should continue to increase with increasing $\mathrm{In}_{2} \mathrm{O}_{3}$ content as the bcc $\operatorname{In}_{2} \mathrm{O}_{3}$ (ss) increases in this two-phase region, reaching values near that for $\mathrm{In}_{2} \mathrm{O}_{3},<10^{2}(\mathrm{ohm}-\mathrm{cm})^{-1}$. The electrical

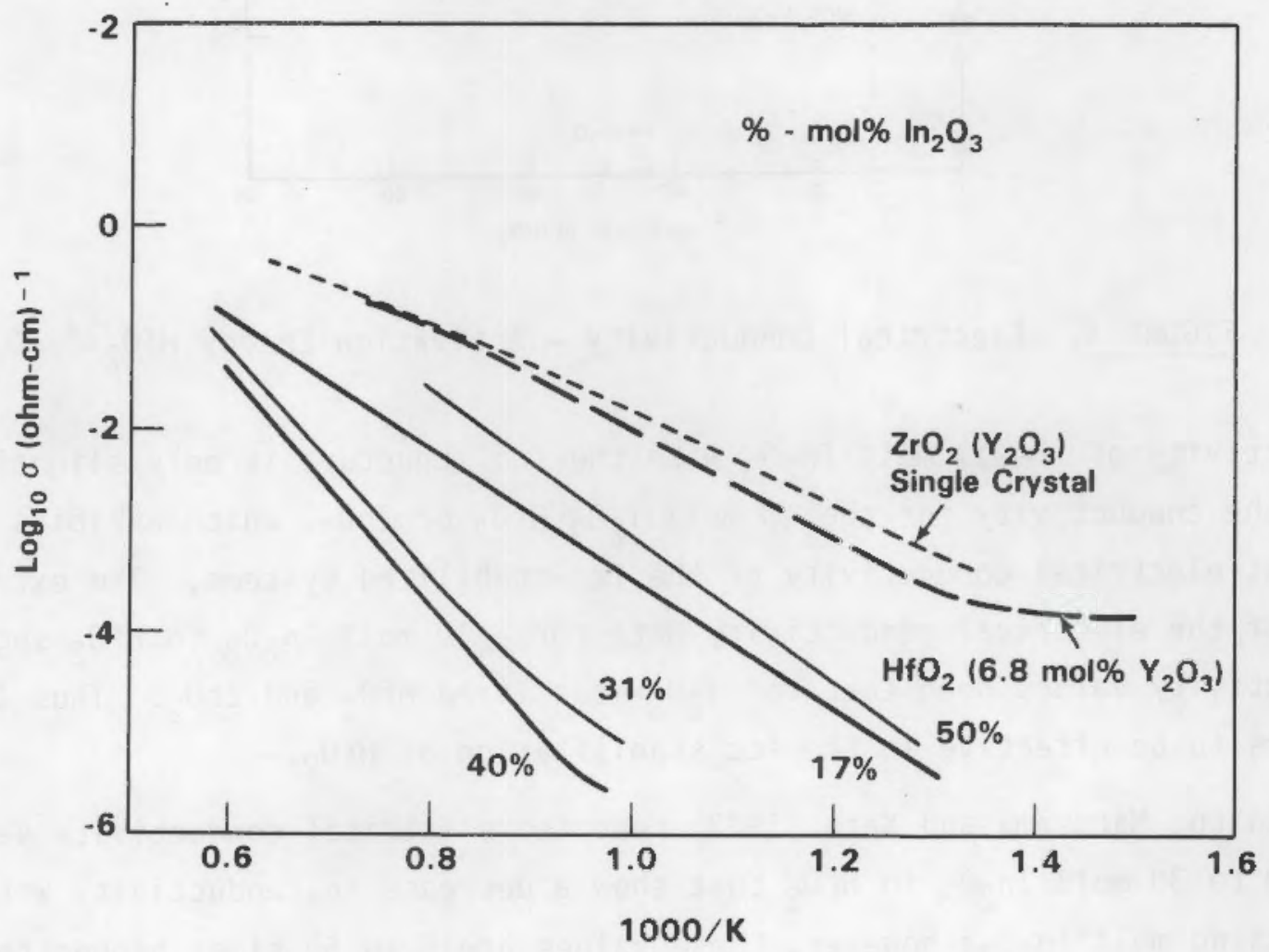

FIGURE 4. Electrical Conductivity of $\mathrm{HfO}_{2}-\mathrm{In}_{2} \mathrm{O}_{3}, \mathrm{ZrO}_{2}\left(\mathrm{Y}_{2} \mathrm{O}_{3}\right)$ Single Crystal and $\mathrm{HfO}_{2}\left(\mathrm{Y}_{2} \mathrm{O}_{3}\right)$. Percentages are mol\% $\operatorname{In}_{2} \mathrm{O}_{3}^{2}$. 


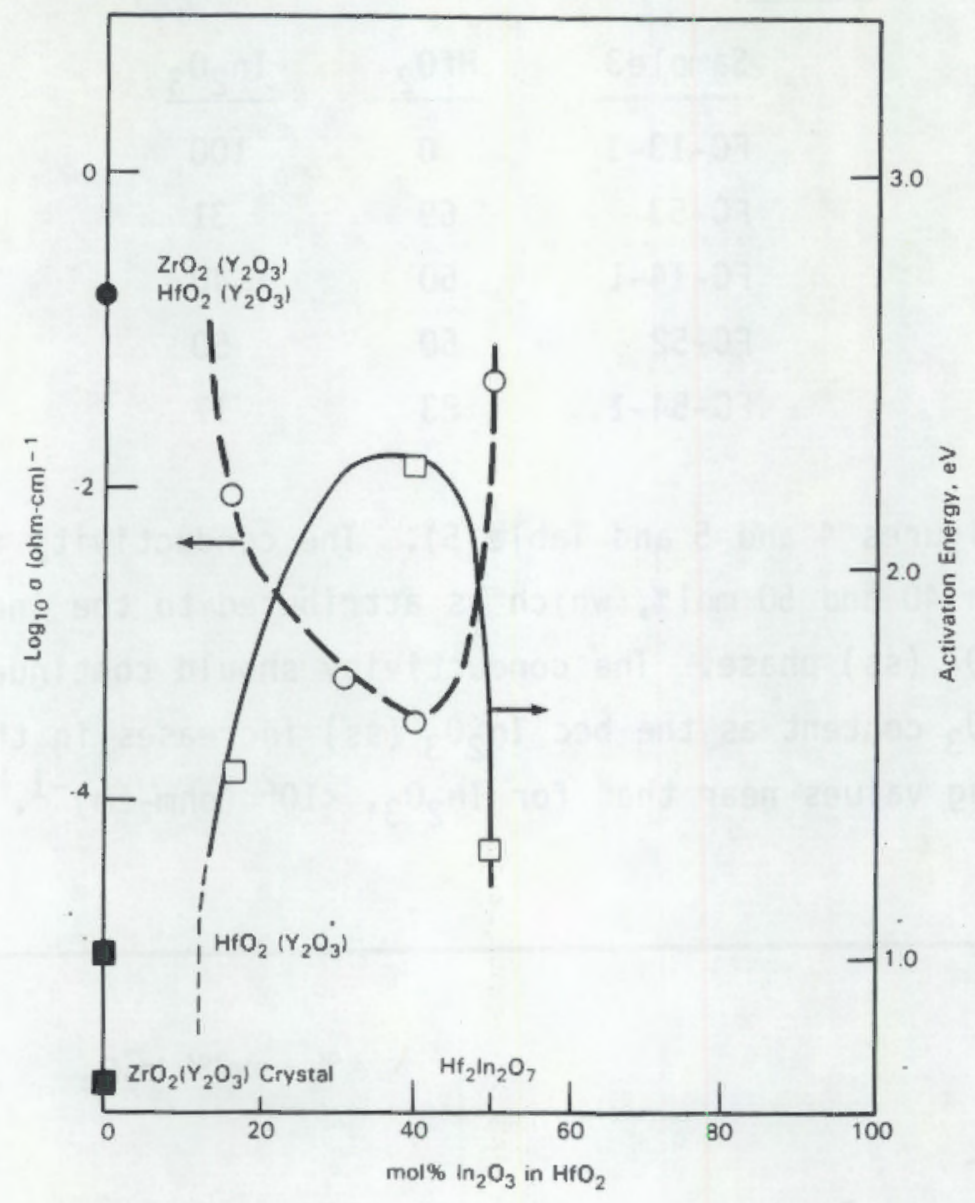

FIGURE 5. Electrical Conductivity - Activation Energy $\mathrm{HfO}_{2}-\mathrm{In}_{2} \mathrm{O}_{3}$

conductivity of the $17 \mathrm{~mol}_{\%} \mathrm{In}_{2} \mathrm{O}_{3}$ with the fec structure is only slightly lower than the conductivity for the $10 \mathrm{~mol} \% \mathrm{Y}_{2} \mathrm{O}_{3} \mathrm{HfO}_{2}$ or $\mathrm{ZrO}_{2}$, which exhibits the highest electrical conductivity of the fcc-stabilized systems. The extrapolation of the electrical conductivity data for a $10 \mathrm{~mol}_{2} \mathrm{In}_{2} \mathrm{O}_{3}$ in $\mathrm{HfO}_{2}$ suggests conductivity values near that for $\mathrm{Y}_{2} \mathrm{O}_{3}$-stabilized $\mathrm{HfO}_{2}$ and $\mathrm{ZrO}_{2}$. Thus $\mathrm{In}_{2} \mathrm{O}_{3}$ appears to be effective in the fcc stabilization of $\mathrm{HfO}_{2}$.

Saito, Maruyama and Kato (1983) reported electrical conductivity values for 20 to $30 \mathrm{~mol} \% \mathrm{In}_{2} \mathrm{O}_{3}$ in $\mathrm{HfO}_{2}$ that show a decrease in conductivity with increasing mol\% $\mathrm{In}_{2} \mathrm{O}_{3}$; however, these values are 5 to 50 times higher than those in the present study. The activation energy was reported to be nearly constant ( $1.7 \mathrm{eV})$ over this composition range, while those of this study varied from 1.2 to $2.3 \mathrm{eV}$ (Figure 5). These differences are attributed to the 
TABLE 5. Compositions and Electrical Conductivity of $\mathrm{HfO}_{2}-\mathrm{In}_{2} \mathrm{O}_{3}$

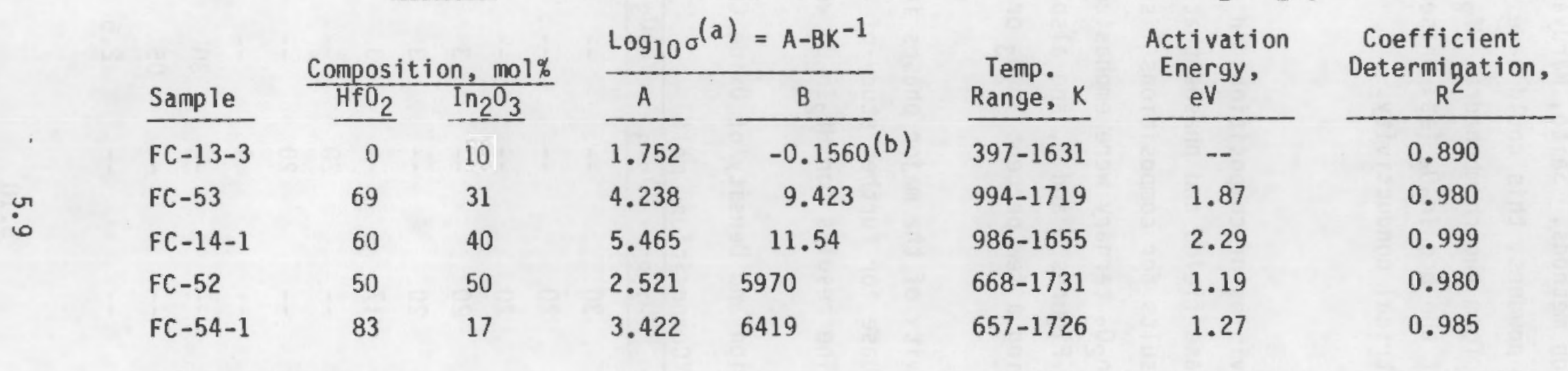

(a) $(\mathrm{ohm}-\mathrm{cm})^{-1}$.

(b) Slope is positive. 
differences in the fabrication methods. Saito, Maruyama and Kato sintered admixtures of $\mathrm{HfO}_{2}$ and $\mathrm{In}_{2} \mathrm{O}_{3}$ powders; this could have resulted in inhomogeneous structures, the inability to form the rhombohedral $\mathrm{Hf}_{2} \mathrm{In}_{2}{ }^{0} 7$ phase during sintering and the presence of the bcc $\operatorname{In}_{2} \mathrm{O}_{3}$ (ss) phase at lower $\operatorname{In}_{2} \mathrm{O}_{3}$ content, which results in higher electrical conductivity.

\section{$5.3 \mathrm{HfO}_{2}-\mathrm{RE}_{\mathrm{X}} \mathrm{O}_{4}-\mathrm{In}_{2} \mathrm{O}_{3}$}

The electrical conductivities of compositions in the $\mathrm{HfO}_{2}-\mathrm{RE}_{x} \mathrm{O}_{y}-\mathrm{In}_{2} \mathrm{O}_{3}$ were measured to determine the phase fields and phases that exhibit the highest electrical conductivity. Results for compositions listed in Table 6 in the center of the $\mathrm{HfO}_{2}-\mathrm{PrO}_{1.83^{-}} \mathrm{In}_{2} \mathrm{O}_{3}$ ternary were emphasized; these results are summarized in Table 7 and in Figures 6 and 7 , and also include samples with similar compositions containing a few percent $\mathrm{Yb}_{2} \mathrm{O}_{3}$ or other rare-earth oxides.

The electrical conductivity of the major phases in the $\mathrm{HfO}_{2}-\mathrm{PrO}_{1.83^{-}} \mathrm{In}_{2} \mathrm{O}_{3}$ system were determined as a base for further study of the two- and three-phase structures in this system. The results for $\mathrm{Hf}_{2} \mathrm{In}_{2} \mathrm{O}_{7}$ were discussed

TABLE 6. Composition and Density of Oxide Current Leadouts

\begin{tabular}{|c|c|c|c|c|c|c|c|}
\hline & & & Compositic & , mol\% & & & Density, \\
\hline & $\mathrm{HfO}_{2}$ & $\mathrm{In}_{2} \mathrm{O}_{3}$ & $\mathrm{PrO}_{1.83}$ & $\mathrm{Y}_{2} \mathrm{O}_{3}$ & $\mathrm{Yb}_{2} \mathrm{O}_{3}$ & $\mathrm{~Tb}_{4} \mathrm{O}_{7}$ & $\mathrm{~g} / \mathrm{cm}^{3}$ \\
\hline BB & 25 & 45 & 30 & -- & -- & - & 7.056 \\
\hline B-4 & 25 & 55 & 20 & -- & -- & -- & 8.818 \\
\hline $8-5$ & 25 & 55 & 20 & -- & -- & -- & 9.022 \\
\hline LLL - 40 & 47 & 30 & 20 & -- & 3 & -- & 7.537 \\
\hline LLL -44 & 47 & 30 & 20 & -- & 3 & -- & 7.618 \\
\hline KKK & 41 & 39 & 17 & -- & 3 & -- & 5.975 \\
\hline Z & 25 & 55 & -- & 20 & -- & - & 7.557 \\
\hline$Y$ & 25 & 55 & -- & 20 & - & -- & 6.649 \\
\hline MMM & 49 & 43 & -- & 4 & - & 4 & 7.330 \\
\hline AA & 25 & 45 & -- & - & 30 & -- & 7.207 \\
\hline $\mathrm{EE}$ & 89 & 05 & -- & -- & 05 & - & 7.970 \\
\hline CC & 96 & 01.5 & -- & -- & 2.5 & -- & 0.998 \\
\hline
\end{tabular}


TABLE 7. Electrical Conductivity of 0xide Current Leadouts Electrical Conductivity $(S / M) \log _{10} \sigma=A-B\left(K^{-1}\right)$

High Temperature

$\frac{\text { A }}{5.462} \frac{\mathrm{B}}{1.970 \times 10^{3}} \frac{\mathrm{eV}}{0.391} \frac{\mathrm{K}}{800-1434}$

BB

$$
\text { B-4 } 5.160 \quad 1.904 \times 10^{3} \quad 0.378 \quad 895-1651^{(a)}
$$

$$
8-5 \quad 5.206 \quad 1.927 \times 10^{3} \quad 0.383 \quad 898-1649(\mathrm{a})
$$

$$
\text { LLL }-40
$$

5.273

0.56

$$
\text { 997-1508 }
$$

$0.660 \quad 1151-1551$

LLL -44

5.530

$3.325 \times 10^{3}$

$$
6.496
$$

$3.120 \times 10^{3}$

0.620

950-1491

$$
7.289
$$

$7.616 \times 10^{3}$

1.51

940-1450

$Y \quad 7.289$
Y

MMM $\quad 5.275$

$5.798 \times 10^{3}$

1.15

940-1350

$2.038 \times 10^{3}$

0.405

829-1556

900-1452

AA

7.207

$9.034 \times 10^{3}$

1.79

$697-1415$

\section{CC}

$$
4.908
$$

$5.060 \times 10^{3}$

1.00

AF -1

4.346

$4.644 \times 10^{3}$

0.912

$770-1538$

AG-1

4.378

$9.695 \times 10^{3}$

1.925

1324-1503

0.63

930-1725

$\mathrm{AB}-1$

0.55

987-1647

\section{Low Temperature}

\begin{tabular}{llllll}
\hline \multicolumn{1}{c}{$\mathrm{A}$} & & $\mathrm{B}$ & $\mathrm{eV}$ & $\mathrm{K}$ \\
\hline 4.1278 & & $8.811 \times 10^{2}$ & 0.175 & & $562-763$ \\
3.005 & & $2.498 \times 10^{3}$ & 0.050 & $299-562$ \\
4.188 & & $1.051 \times 10^{3}$ & 0.209 & $697-895$ \\
2.8052 & $8.240 \times 10^{2}$ & 0.164 & $398-697$
\end{tabular}

3.516

$9.953 \times 10^{2}$

$0.198 \quad 646-997(a)$

3.758

$1.375 \times 10^{3}$

$0.273 \quad 851-1052$

4.045

$7.773 \times 10^{2}$

0.154

612-950(a)

2.1517

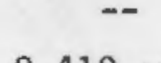

$8.410 \times 10^{3}$

0.167

$--$

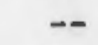

(b)

4. 855

$1.758 \times 10^{3}$

0.173

$665-900$

--

-0.5501
-0.449
1.138

$-3.596 \times 10^{3}$

0.71

791-1242

$8.118 \times 10^{2}$

0.16

643-930

$2.544 \times 10^{2}$

0.05

$335-930$

(a) Difference on heating and cooling.

(b) Data irregular at low temperatures; e.g., higher scatter at room temperature. 


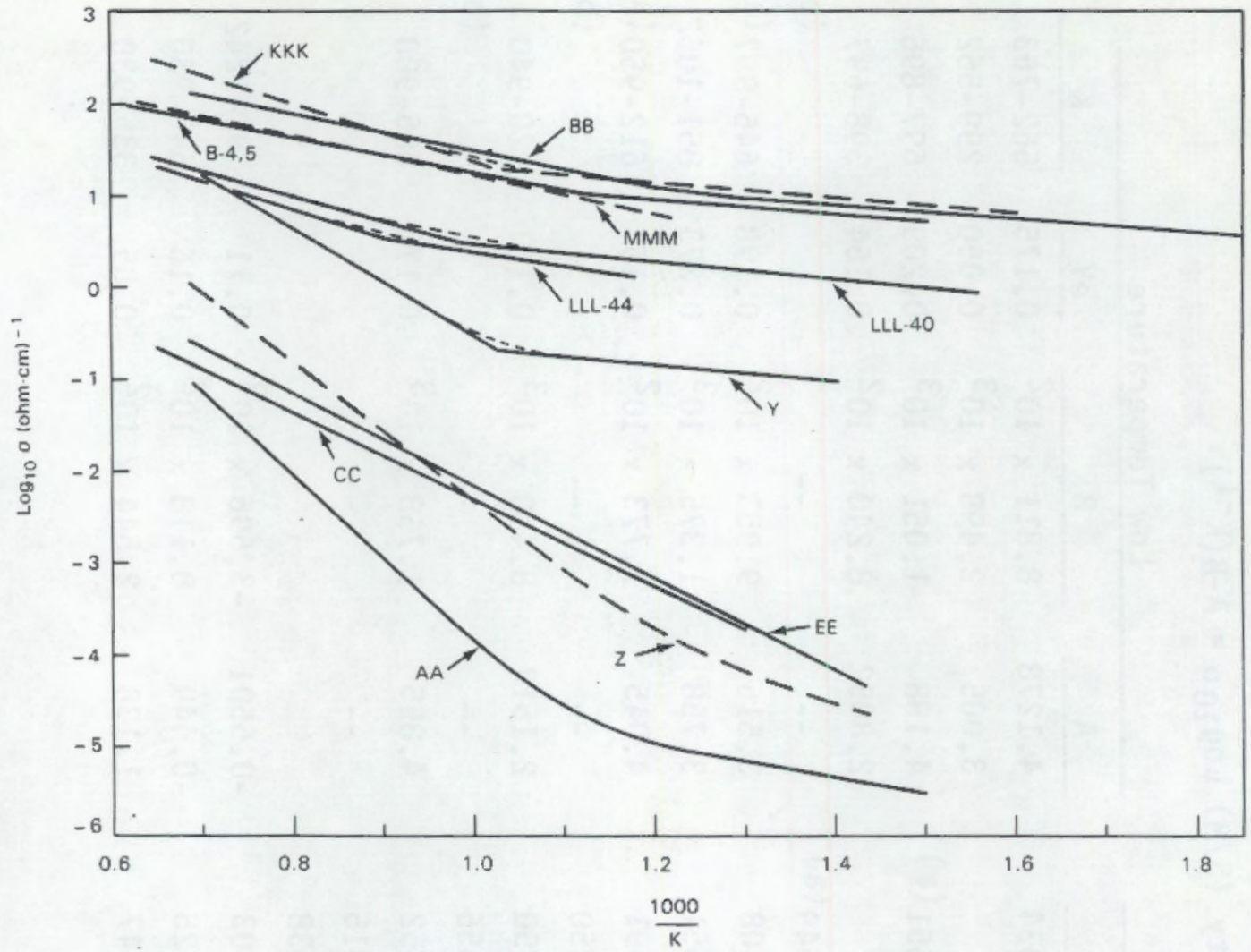

FIGURE 6. Electrical Conductivity of 0xide Current Leadouts

previously. The electrical conductivity of the orthorhombic $\mathrm{PrInO} \mathrm{O}_{3}$ and the pyrochlore $\mathrm{Hf}_{2} \mathrm{Pr}_{2} \mathrm{O}_{7}$ is low, with values between $10^{-3}$ and $10^{-4}$ (ohm-cm) ${ }^{-1}$ at $1273 \mathrm{~K}$ and a high temperature dependence. The electrical conductivity of the monoclinic $\mathrm{HfO}_{2}$ is even lower, $10^{-4}$ to $10^{-5}$ (ohm-cm $)^{-1}$.

\section{$5.4 \mathrm{HfO}_{2}-\operatorname{PrO}_{1.83}-\mathrm{In}_{2} \mathrm{O}_{3}$}

The single-phase bcc $\mathrm{In}_{2} \mathrm{O}_{3}$ (ss) containing $\mathrm{HfO}_{2}$ and/or $\mathrm{PrO}_{1.83}$ exhibits the highest electrical conductivity, $\left\langle 10^{2}(\mathrm{ohm}-\mathrm{cm})^{-1}\right.$, and a very small temperature dependence. Those phases fields associated with this bcc $\operatorname{In}_{2} \mathrm{O}_{3}$ (ss) also have high electrical conductivities. This includes the two-phase fields containing either the $\mathrm{Hf}_{2} \mathrm{Pr}_{2} \mathrm{O}_{7}$ or $\mathrm{Hf}_{2} \mathrm{In}_{2} \mathrm{O}_{7}$ phases or the two three-phase fields that border on them. Using the preliminary phase diagram for the $\mathrm{HfO}_{2}-\mathrm{PrO}_{1.83^{-}}$ $\mathrm{In}_{2} \mathrm{O}_{3}$ system shown in Figure 2, the concentration of the bcc $\operatorname{In}_{2} \mathrm{O}_{3}$ (ss) was

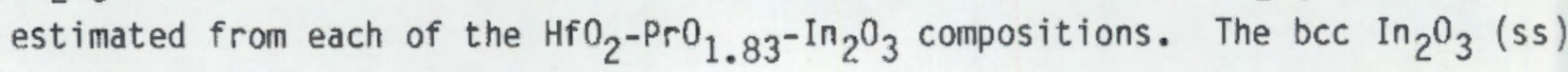




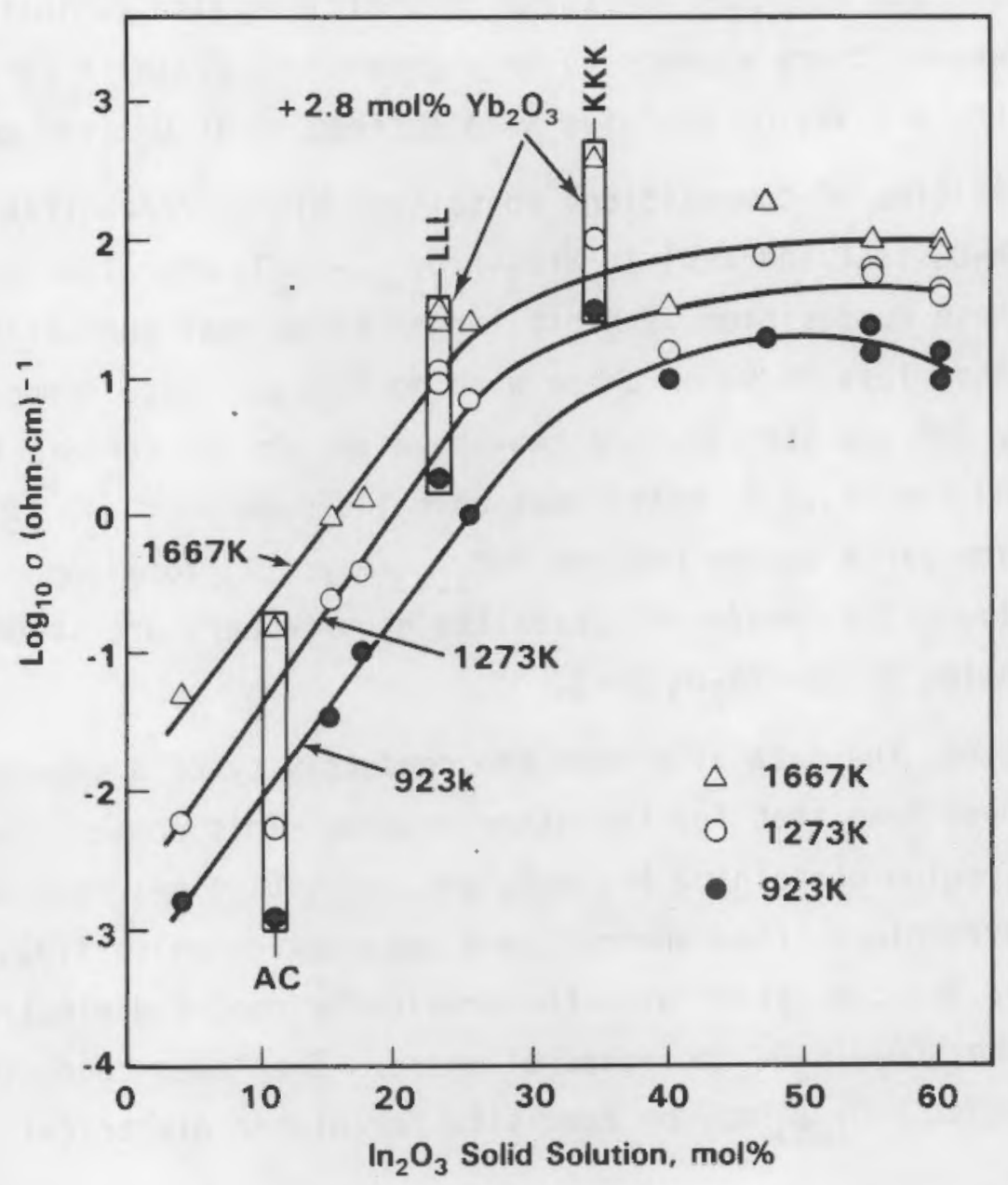

FIGURE 7. Electrical Conductivities of $\mathrm{HfO}_{2}-\operatorname{Pr} \mathrm{O}_{1} .83-\mathrm{In}_{2} \mathrm{O}_{3}$ at $923 \mathrm{~K}$, $1273 \mathrm{~K}$, and $1667 \mathrm{~K}$ as a Function of $\mathrm{In}_{2} \mathrm{O}_{3}^{\circ}$ Content

was assumed to be the major contributor to the overall conductivity. The logarithm of the electrical conductivities as a function of bcc $\mathrm{In}_{2} \mathrm{O}_{3}$ (ss) content at 923K, 1273K, and 1667K shows a nearly linear increase up to $30 \mathrm{~mol} \%$ (Figure 7). At higher concentrations, the data exhibit more scatter but appear to reach a near-constant value at each temperature, up to $60 \mathrm{~mol} \%$ bcc solid solution. It should be noted that all of the compositions above $30 \mathrm{~mol} \%$ in Figure 7 contain some $\mathrm{Yb}_{2} \mathrm{O}_{3}$, with one exception. These data confirm that the

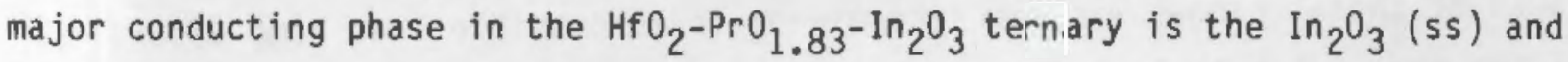
that the maximum conductivity value would be near $100 \mathrm{~mol} \% \mathrm{In}_{2} \mathrm{O}_{3}$, measured previously to be near $100(\text { ohm-cm })^{-1}$. 
The activation energies for these compositions also exhibit significant scatter. However, there appears to be a general decrease in both the high- and low-temperature activation energies with increasing $\mathrm{In}_{2} \mathrm{O}_{3}$ (ss) concentrations.

Conductivities of compositions containing higher concentrations (6 to $3 \mathrm{~mol} \%$ ) of $\mathrm{Yb}_{2} \mathrm{O}_{3}$ (LLL and KKK) in $\mathrm{HfO}_{2}-\mathrm{PrO}_{1.83}-\mathrm{In}_{2} \mathrm{O}_{3}$ are also shown in Figure 7. These compositions exhibit larger electrical conductivities than those containing less $\mathrm{Yb}_{2} \mathrm{O}_{3}$ or those with no $\mathrm{Yb}_{2} \mathrm{O}_{3}$. These compositions, as determined by XRD and SEM-EDX, are two-phase and do not contain the bCC $\mathrm{In}_{2} \mathrm{O}_{3}$ (ss) phase and the $\mathrm{Hf}_{2} \mathrm{In}_{2} \mathrm{O}_{7}$ phase that contains some $\mathrm{PrO}_{1.83^{\circ}}$. This suggests that other rare-earth oxides besides $\operatorname{Pr}_{1.83}$ may: 1) form conducting phases free of the $\mathrm{In}_{2} \mathrm{O}_{3}$ (ss) and/or 2) stabilize high-temperature structures that revert on cooling to the $\mathrm{In}_{2} \mathrm{O}_{3}$ (ss).

In addition, the data also show the conductivity of a two-phase sample (AC) to be lower than that for the other oxides. This composition is in a twophase sample region containing $\mathrm{Hf}_{2} \mathrm{In}_{2} \mathrm{O}_{7}$ and $\mathrm{In}_{2} \mathrm{O}_{3}$ (ss) near the boundary of the three-phase pyrochlore, rhombohedral, and sesquioxide phase field. The lower conductivities are consistent with the previously reported electrical conductivities of the $\mathrm{HfO}_{2}-\mathrm{In}_{2} \mathrm{O}_{3}$ rhombohedral phase. The lower conductivity values also suggest that $\operatorname{PrO}_{1.83}$ may be requisite for higher electrical conductivity.

It has been observed in this study that samples with compositions in or near the two-phase $\mathrm{Hf}_{2} \mathrm{Pr}_{2} \mathrm{O}_{7}$ region may exhibit a hysteresis on heating and cooling during the electrical conductivity measurements (see FC-54-1 in Table 5). Although the oxides were sintered at $1823 \mathrm{~K}$ in air and measurements were made in air, some conductivity changes did occur for some samples. The magnitude of these changes varied among samples.

Generally, the conductivity on cooling was higher than that on heating. For some samples, the two straight lines in the $\log$ o versus $\mathrm{K}^{-1}$ were eliminated and the cooling curve was linear over the entire temperature range. The cause of these changes was not determined; it is possible that some vapor loss of the more volatile $\mathrm{In}_{2} \mathrm{O}_{3}$ may have resulted in a compositional change, 
especially near the sample surface. In addition, as suggested for the $\mathrm{Yb}_{2} \mathrm{O}_{3}$ containing oxides, phase changes may occur during the measurements that change the conductivity values.

\section{$5.5 \mathrm{HfO}_{2}-\mathrm{PrO}_{1.83}-\mathrm{In}_{2} \mathrm{O}_{3}-\mathrm{Yb}_{2} \mathrm{O}_{3}$}

As was observed in Figure 7 , the addition of small amounts of $\mathrm{Yb}_{2} \mathrm{O}_{3}$ to the $\mathrm{HfO}_{2}-\mathrm{PrO}_{2}-\mathrm{In}_{2} \mathrm{O}_{3}$ system increased the electrical conduction. To investigate this effect, the electrical conductivity was measured on a nominal $0.63 \mathrm{HfO}_{2}$. $0.27 \operatorname{PrO}_{1.83^{\circ}} 0.10 \mathrm{YbO}_{1.5}$ base composition containing varied amounts of $\mathrm{In}_{2} \mathrm{O}_{3}$. These compositions had also exhibited good corrosion to molten coal slag and alkali seed. These structures contain both the fluorite and pyrochlore phases in addition to the bcc $\operatorname{In}_{2} \mathrm{O}_{3}$ (ss). The electrical conductivities of the compositions listed in Table 8 are shown in Figure 8 and Table 7.

The results suggest a sharp increase in electrical conductivity near $25 \mathrm{~mol} \% \mathrm{In}_{2} \mathrm{O}_{3}$, with smaller increases above $30 \mathrm{~mol} \%$. The range of compositions for the $\mathrm{Hf}_{2} \mathrm{Pr}_{2} \mathrm{O}_{7}$ single-phase pyrochlore structure was 0.42 to $0.58 \mathrm{~mol} \%$ $\mathrm{HfO}_{2}$. The above compositions were high in $\mathrm{HfO}_{2}$ where both the fluorite and pyrochlore phases were present. The addition of $\mathrm{In}_{2} \mathrm{O}_{3}$ resulted in the formation of a three-phase structure containing the bcc $\operatorname{In}_{2} \mathrm{O}_{3}$ (ss).

To determine the effect of $\mathrm{In}_{2} \mathrm{O}_{3}$ and the bcc $\mathrm{In}_{2} \mathrm{O}_{3}$ (ss) on the pyrochlore structure containing $\mathrm{Yb}_{2} \mathrm{O}_{3}$ without the fluorite phase, a series of compositions containing equal amounts of $\mathrm{HfO}_{2}$ and $\mathrm{PrO}_{1.83}$ and $6 \mathrm{~mol} \% \mathrm{Yb}_{2} \mathrm{O}_{3}$ with varying amounts of $\mathrm{In}_{2} \mathrm{O}_{3}$ were studied in air to $1820 \mathrm{~K}$ (Table 9). The five compositions were $(0.94-\chi)\left[0.5 \mathrm{HfO}_{2} \cdot 0.5 \mathrm{Pr}_{1}{ }_{1.83}\right] \cdot \chi \mathrm{In}_{2} \mathrm{O}_{3} \cdot 0.06 \mathrm{Yb}_{2} \mathrm{O}_{3}$ with $\chi$ between 20 and $40 \mathrm{~mol} \%$; see Table 10 . The weight ratio of the bcc $\mathrm{In}_{2} \mathrm{O}_{3}$ (ss) and pyrochlore

TABLE 8. Compositions of $\mathrm{HfO}_{2}-\mathrm{PrO}_{1.83}-\mathrm{In}_{2} \mathrm{O}_{3}$ Containing $\mathrm{Yb}_{2} \mathrm{O}_{3}$

$\begin{array}{ll}\text { AF }-1 & 0.85\left(0.27 \mathrm{PrO}_{2} \cdot 0.63 \mathrm{HfO}_{2} \cdot 0.10 \mathrm{YbO}_{1} \cdot 5\right) \cdot 0.15 \mathrm{In}_{2} \mathrm{O}_{3} \\ \text { AG-1 } & 0.75\left(0.27 \mathrm{PrO}_{2} \cdot 0.63 \mathrm{HfO}_{2} \cdot 0.10 \mathrm{YbO}_{1.5}\right) \cdot 0.25 \mathrm{In}_{2} \mathrm{O}_{3} \\ \text { LLL } & 0.70\left(0.27 \mathrm{PrO}_{2} \cdot 0.64 \mathrm{HfO}_{2} \cdot 0.09 \mathrm{YbO}_{1.5}\right) \cdot 0.30 \mathrm{In}_{2} \mathrm{O}_{3} \\ \text { AB-1 } & 0.43\left(0.27 \mathrm{PrO}_{2} \cdot 0.63 \mathrm{HfO}_{2} \cdot 0.10 \mathrm{YbO}_{1.5}\right) \cdot 0.57 \mathrm{In}_{2} \mathrm{O}_{3} \\ \text { BB } & 0.55\left(0.55 \mathrm{PrO}_{2} \cdot 0.45 \mathrm{HfO}_{2}\right) \cdot 0.45 \mathrm{In}_{2} \mathrm{O}_{3} \\ \text { KKK } & 0.61\left(0.27 \mathrm{PrO}_{2} \cdot 0.64 \mathrm{HfO}_{2} \cdot 0.09 \mathrm{YbO}_{1.5}\right) \cdot 0.39 \mathrm{In}_{2} \mathrm{O}_{3}\end{array}$




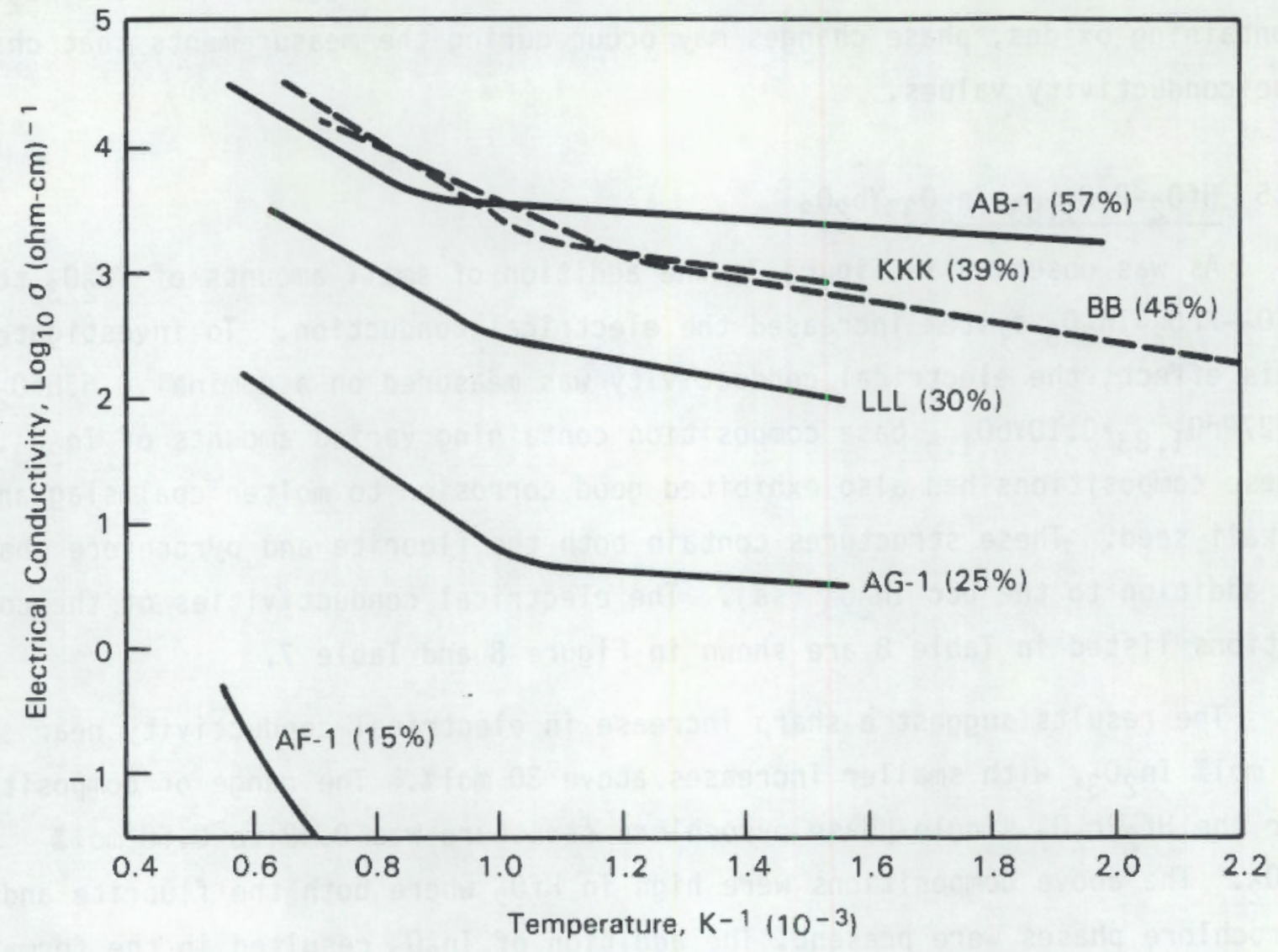

FIGURE 8. Electrical Conductivity of Current Leadout Materials

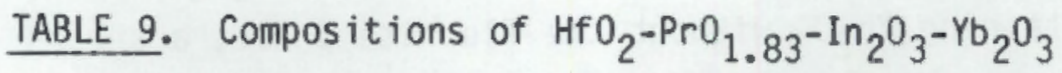

\begin{tabular}{|c|c|c|c|c|c|c|}
\hline \multirow[b]{2}{*}{ Sample } & \multicolumn{4}{|c|}{ Composition, mol\% } & \multicolumn{2}{|c|}{ Phases, wt \% } \\
\hline & $\mathrm{HfO}_{2}$ & $\mathrm{PrO}_{1.83}$ & $\mathrm{In}_{2} \mathrm{O}_{3}$ & $\mathrm{Yb}_{2} \mathrm{O}_{3}$ & Pyrochlore & $\mathrm{bcc}$ \\
\hline FC -157 & 27 & 27 & 40 & 6 & 50 & 50 \\
\hline$F C-153$ & 29.5 & 29.5 & 35 & 6 & 55 & 45 \\
\hline $\mathrm{FC}-154$ & 32 & 32 & 30 & 6 & 65 & 35 \\
\hline$F C-155$ & 34.5 & 34.5 & 25 & 6 & 60 & 40 \\
\hline$F C-156$ & 37 & 37 & 20 & 6 & 67 & 33 \\
\hline
\end{tabular}


TABLE 10. Electrical Conductivity of $\mathrm{HfO}_{2}-\mathrm{PrO}_{1.83}-\mathrm{In}_{2} \mathrm{O}_{3}-\mathrm{Yb}_{2} \mathrm{O}_{3}$

\begin{tabular}{|c|c|c|c|c|c|}
\hline Sample & $\frac{\log \sigma}{A}$ & $=\frac{A-B / K}{B\left(10^{S}\right)}$ & $\begin{array}{c}\text { Temperature } \\
\text { Range, } \\
\mathrm{K}\end{array}$ & $\begin{array}{c}\begin{array}{c}\text { Activation } \\
\text { Energy, } \\
\mathrm{eV}\end{array} \\
\end{array}$ & $\begin{array}{l}\text { Coefficient of } \\
\text { Determination }\end{array}$ \\
\hline FC -157 & $\begin{array}{l}4.268 \\
1.094\end{array}$ & $\begin{array}{l}4.253 \\
0.777\end{array}$ & $\begin{array}{r}1109-1576 \\
578-1109\end{array}$ & $\begin{array}{l}0.84 \\
0.15\end{array}$ & $\begin{array}{l}0.992 \\
0.922\end{array}$ \\
\hline $\mathrm{FC}-157 \mathrm{HT}^{(\mathrm{a})}$ & $\begin{array}{l}4.841 \\
1.551\end{array}$ & $\begin{array}{l}5.376 \\
2.482\end{array}$ & $\begin{array}{r}879-1579 \\
503-879\end{array}$ & $\begin{array}{l}1.07 \\
0.49\end{array}$ & $\begin{array}{l}0.994 \\
0.984\end{array}$ \\
\hline FC- 153 & $\begin{array}{l}5.020 \\
2.035\end{array}$ & $\begin{array}{l}5.892 \\
3.259\end{array}$ & $\begin{array}{r}890-1588 \\
503-890\end{array}$ & $\begin{array}{l}1.17 \\
0.65\end{array}$ & $\begin{array}{l}0.998 \\
0.992\end{array}$ \\
\hline $\mathrm{FC}-153 \mathrm{HT}$ & $\begin{array}{l}4.968 \\
2.335\end{array}$ & $\begin{array}{l}5.960 \\
3.577\end{array}$ & $\begin{array}{r}888-1580 \\
518-\quad 888\end{array}$ & $\begin{array}{l}1.18 \\
0.71\end{array}$ & $\begin{array}{l}0.996 \\
0.997\end{array}$ \\
\hline FC- 154 & $\begin{array}{l}4.657 \\
1.771\end{array}$ & $\begin{array}{l}5.910 \\
3.377\end{array}$ & $\begin{array}{l}885-1597 \\
510-885\end{array}$ & $\begin{array}{l}1.17 \\
0.66\end{array}$ & $\begin{array}{l}0.994 \\
0.995\end{array}$ \\
\hline $\mathrm{FC}-154 \mathrm{HT}$ & 4.944 & 6.404 & $104-1575$ & 1.27 & 0.995 \\
\hline FC -155 & $\begin{array}{r}3.524 \\
-0.656\end{array}$ & $\begin{array}{l}5.517 \\
1.841\end{array}$ & $\begin{array}{r}878-1599 \\
500-878\end{array}$ & $\begin{array}{l}1.10 \\
0.37\end{array}$ & $\begin{array}{l}0.984 \\
0.874\end{array}$ \\
\hline FC- 156 & $\begin{array}{l}2.969 \\
1.367\end{array}$ & $\begin{array}{l}4.163 \\
3.313\end{array}$ & $\begin{array}{r}1101-1564 \\
552-1101\end{array}$ & $\begin{array}{l}0.95 \\
0.66\end{array}$ & $\begin{array}{l}0.990 \\
0.996\end{array}$ \\
\hline $\mathrm{FC}-156 \mathrm{HT}$ & $\begin{array}{r}2.972 \\
-0.139\end{array}$ & $\begin{array}{l}4.798 \\
2.084\end{array}$ & $\begin{array}{r}868-1578 \\
534-868\end{array}$ & $\begin{array}{l}0.95 \\
0.41\end{array}$ & $\begin{array}{l}0.986 \\
0.962\end{array}$ \\
\hline
\end{tabular}

(a) $H T=$ Heat treated in air at $1820 \mathrm{~K}$ for $48 \mathrm{~h}$.

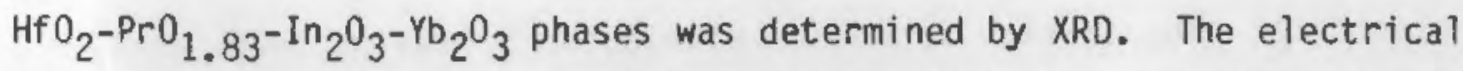
conductivities were determined from 500 to $1600 \mathrm{~K}$ in air (Table 10 and Figure 9) and after heat treatment in air at 1820K for 48 hours (Figure 10).

The electrical conductivity data were fitted to $\log$ o versus $k^{-1}$ with two straight lines intercepting near 900K. The electrical conductivities were changed by heat treatment. A large decrease in conductivity was noted for the composition with the highest $\mathrm{In}_{2} \mathrm{O}_{3}$ content, $\mathrm{FC}-157(40 \mathrm{~mol} \%)$. In contrast, the composition with the lowest indium content--FC-156 with 20 mol\%--exhibited little change at high temperatures. Below 900K, the conductivity of the heattreated sample was higher than the as-fabricated sample. These changes may 


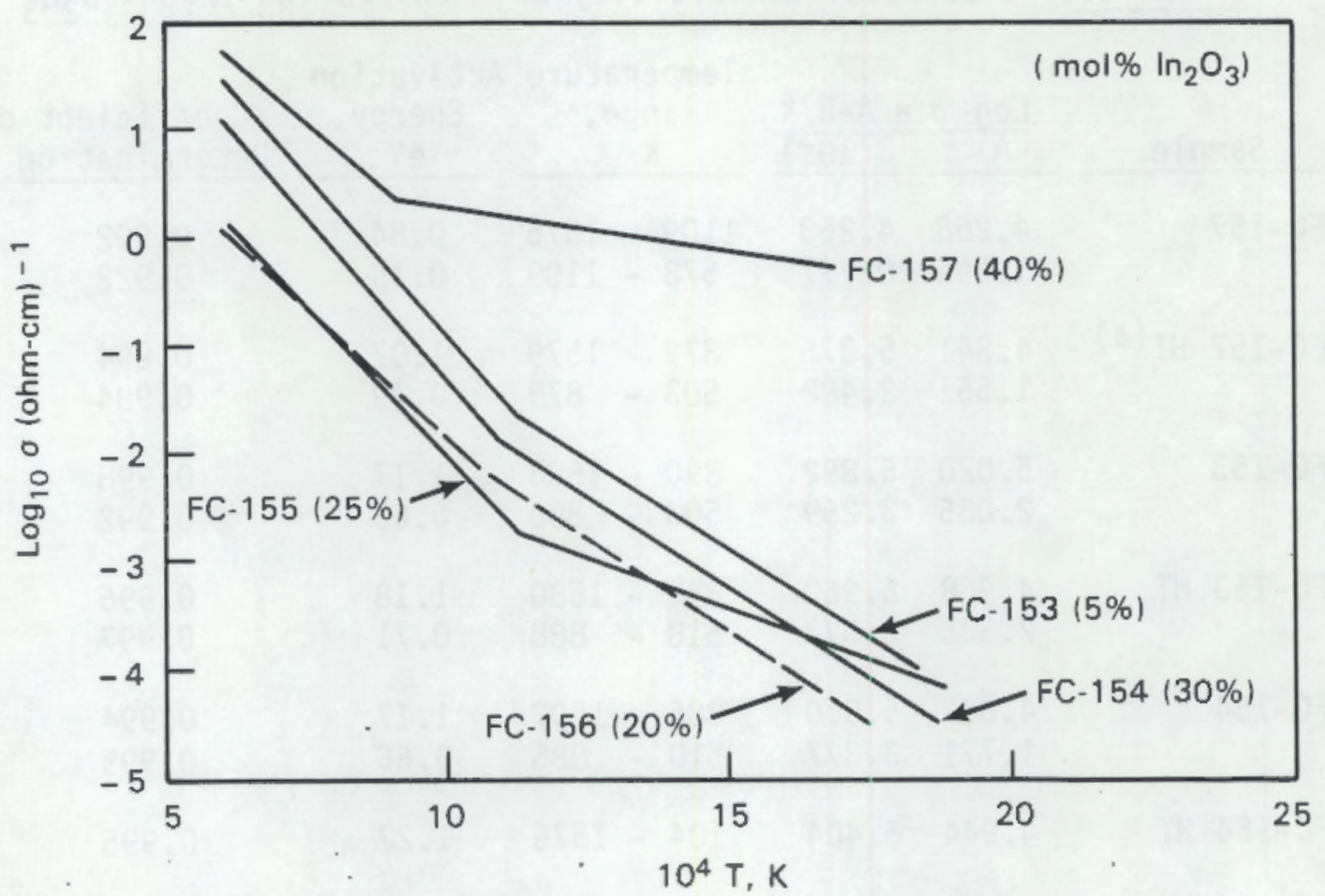

FIGURE 9. Electrical Conductivity of $(0.96-x) \cdot\left[0.5 \mathrm{HfO}_{2}\right.$ $\left.0.5 \mathrm{PrO}_{2}\right] \cdot x\left(\mathrm{In}_{2} \mathrm{O}_{3}\right) \cdot 0.06 \mathrm{Yb}_{2} \mathrm{O}_{3}$ in Air

relate to the loss of $\mathrm{In}_{2} \mathrm{O}_{3}$ or $\mathrm{PrO}_{2}$ during heat treatment. All heat-treated samples experienced some small weight loss. The greatest loss was observed for the higher-In $2_{3} \mathrm{O}_{3}$ oxides. However, XRD before and after heat treatment exhibited the same bcc and pyrochlore structures with only a slight increase in the bcc $\mathrm{In}_{2} \mathrm{O}_{3}$ (ss) phase.

The electrical conductivity increased with both increasing $\operatorname{In}_{2} \mathrm{O}_{3}$ content and bcc phase content. At 1270K, a plot of $\log \sigma$ versus mol\% in $\mathrm{In}_{2} \mathrm{O}_{3}$ was nearly linear. The $25 \mathrm{~mol}_{\%} \mathrm{In}_{2} \mathrm{O}_{3}$ composition deviated from this general pattern. This composition exhibited a higher bcc phase concentration, a lower electrical conductivity, and an activation energy different from that expected from other trends in the data.

Thus, a number of compositions in the $\mathrm{HfO}_{2}-\mathrm{RE}_{x} \mathrm{O}_{y}-\mathrm{In}_{2} \mathrm{O}_{3}$ system, especially those with $\mathrm{HfO}_{2}-\mathrm{PrO}_{2}-\mathrm{In}_{2} \mathrm{O}_{3}$ containing $\mathrm{Yb}_{2} \mathrm{O}_{3}$, have electrical properties suitable as electrode current interconnectors for use in the graded ceramic 


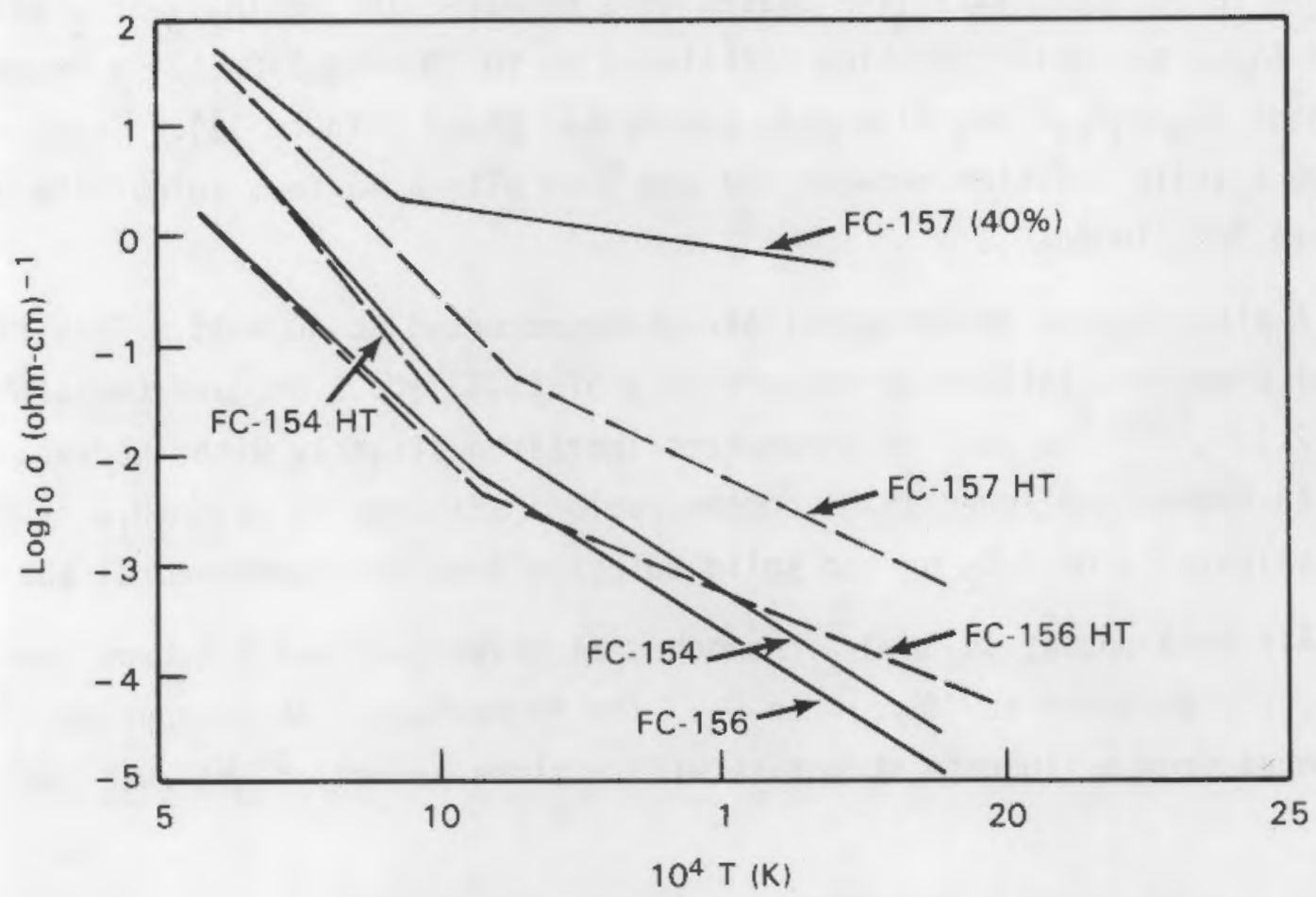

FIGURE 10. Electrical Conductivity of $(0.94-\chi) \cdot\left[0.5 \mathrm{HfO}_{2}\right.$ $\left.0.5 \mathrm{PrO}_{2}\right] \cdot \chi\left(\mathrm{In}_{2} \mathrm{O}_{3}\right) \cdot 0.06 \mathrm{Yb}_{2} \mathrm{O}_{3}$ Before and After Heat Treatment to $1820 \mathrm{~K}$ for $48 \mathrm{~h}(\mathrm{HT})$

composite electrode system. The compositions that appear most promising are those two- and three-phase structures that contain between 30 and $45 \mathrm{~mol} \%$ of the bcc $\mathrm{In}_{2} \mathrm{O}_{3}$ (ss) phase.

\section{$5.6 \quad \mathrm{In}_{2} \mathrm{O}_{3}-\mathrm{SnO}_{2}$}

Indium oxide-tin oxide compositions were considered as a substitute for $\mathrm{In}_{2} \mathrm{O}_{3}$ in MHD current interconnectors to increase the electrical conductivity of $\mathrm{HfO}_{2}-\mathrm{RE}_{\mathrm{x}} \mathrm{O}_{\mathrm{y}}-\mathrm{In}_{2} \mathrm{O}_{3}$. The results of this study have been published (Bates et al. 1986); the data and conclusions are summarized here.

The $\mathrm{In}_{2} \mathrm{O}_{3}-\mathrm{SnO}_{2}$ compositions were made from coprecipitated powders that were cold pressed into rectangular bars and sintered in air between $1800 \mathrm{~K}$ and 1850K. The final densities varied between $60 \%$ and $80 \%$ of the theoretical density. 
Three stable crystalline phases were observed in the $\mathrm{In}_{2} \mathrm{O}_{3}-\mathrm{SnO}_{2}$ system: 1) an $\mathrm{In}_{2} \mathrm{O}_{3}$ bcc solid solution containing up to $20 \mathrm{~mol} \% \mathrm{SnO}_{2} ; 2$ ) a rhombohedral phase of $\mathrm{In}_{4} \mathrm{Sn}_{3} \mathrm{O}_{12}$; and 3 ) a $\mathrm{SnO}_{2}$ tetragonal phase (Figure 11). In $\mathrm{In}_{2} \mathrm{O}_{3}$ and $\mathrm{SnO}_{2}$ formed a solid solution between $80 \%$ and $100 \%$ with a maximum solubility of $20 \mathrm{~mol}_{\%} \mathrm{SnO}_{2}$ in $\mathrm{In}_{2} \mathrm{O}_{3}$.

A single-phase rhombohedral structure occurred at $40 \mathrm{~mol} \%$. This rhombohedral phase had lattice parameters $\left(a_{0}\right)$ of $80.43 \pm 0.01 \mathrm{~nm}$, and the alpha angle was $72.12^{\circ}$. (a) The lattice parameters increased slightly with increasing $\mathrm{In}_{2} \mathrm{O}_{3}$ at both higher and lower $\mathrm{In}_{2} \mathrm{O}_{3}$ concentrations adjacent to $\mathrm{In}_{4} \mathrm{Sn}_{3} \mathrm{O}_{12}$, suggesting some solubility of $\mathrm{SnO}_{2}$ or bcc solid solution into the rhombohedral phase.

A single-phase, $\mathrm{In}_{4} \mathrm{Sn}_{3} \mathrm{O}_{12}$ rhombohedral phase that had not been reported previously occurred at $40 \mathrm{~mol} \% \mathrm{In}_{2} \mathrm{O}_{3}$. The rhombohedral phase appeared to be developed from a fluorite structure with a close-packed, $M^{\prime}{ }_{m}{ }^{M}{ }^{\prime}{ }_{n}{ }{ }_{3 m}$ complex.

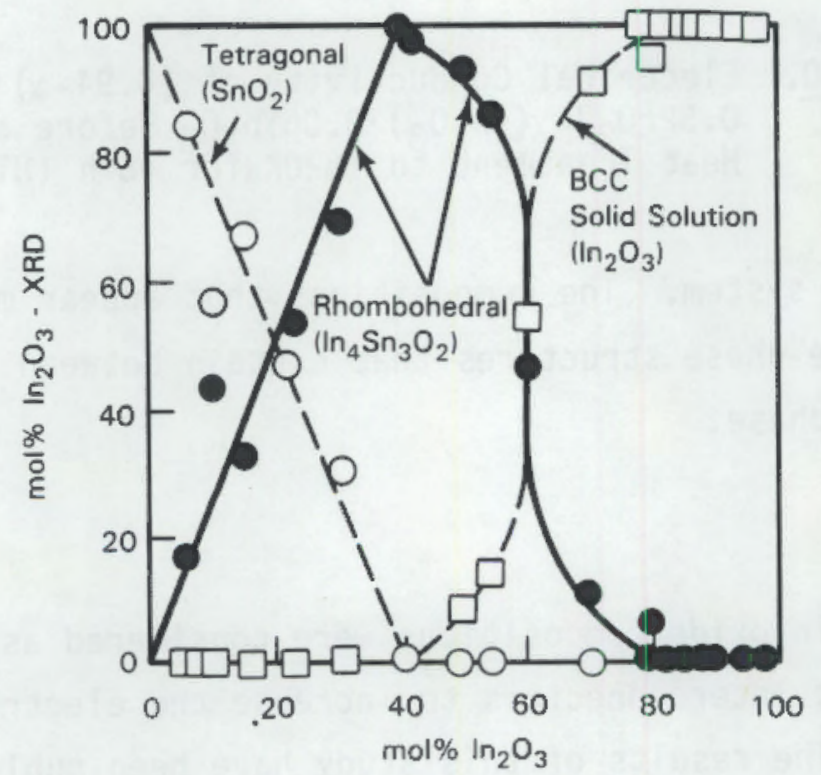

FIGURE 11. Phases at $1123 \mathrm{~K}$ in Air for $\mathrm{In}_{2} \mathrm{O}_{3}-\mathrm{SnO}_{2}$ as a Function of $\mathrm{In}_{2} \mathrm{O}_{3}$ Content Determined by XRD

(a) For simplification in the analysis, a rhombohedral phase is generally expressed as an equivalent hexagonal cell using the hexagonal nomenclature $\left(a_{0}\right.$ and $\left.c_{0}\right)$ to describe the lattice parameters. The lattice parameters for an equivalent hexagonal cell are $a_{0}=94.77 \mathrm{~nm}$ and $c_{0}=117.96 \mathrm{~nm}$. 
Prolonged heating of the single-phase oxide at temperatures between $1173 \mathrm{~K}$ and $1873 \mathrm{~K}$ in air did not produce any observable compositional or structural changes, suggesting that the rhombohedral phase was thermally stable in air to these temperatures. However, as discussed later, electrical transport data do suggest a possible phase change near $1000 \mathrm{~K}$ to $1200 \mathrm{~K}$.

At compositions below $40 \%$, a two-phase structure of tetragonal $\mathrm{SnO}_{2}$ and rhombohedral $\mathrm{In}_{4} \mathrm{Sn}_{3} \mathrm{O}_{12}$ occurred. The relative amounts of these two phases, determined by XRD, suggest little solubility of one in the other. However, the microstructures and the EDX analyses show two distinct phases with no detectable $\mathrm{In}_{2} \mathrm{O}_{3}$ in the $\mathrm{SnO}_{2}$ phase. The small decreases in lattice parameters for the rhombohedral phase with decreasing $\mathrm{In}_{2} \mathrm{O}_{3}$ content suggested some solubility of $\mathrm{SnO}_{2}$ in the $\mathrm{In}_{4} \mathrm{Sn}_{3}{ }_{12}$.

At compositions between $40 \%$ and $80 \%$, both the bcc and rhombohedral phases and possibly a noncrystalline phase were present. The nonlinear distribution of the rhombohedral and bcc phases, with a sharp change near $60 \%$, suggested a more complex structure than just the two crystalline phases.

The electrical conductivities varied as a function of the $\operatorname{In}_{2} \mathrm{O}_{3}$ content. Conductivities increased rapidly with increasing indium concentrations and reached a plateau between $30 \%$ and 50\% (Figure 12 and Table 11). The conductivities increased more slowly at higher indium concentrations, reaching a maximum near $80 \%$. This maximum conductivity was about 25 times larger than that for pure $\ln _{2} \mathrm{O}_{3}$, and 6 to 10 times larger than that for $\operatorname{In}_{4} \mathrm{Sn}_{3} \mathrm{O}_{12}$ (Figure 13 ).

Below $40 \% \operatorname{In}_{2} 0_{3}$, the $\log \sigma$ versus $\mathrm{K}^{-1}$ curve for each composition could be represented by two or three straight lines, with different conductivity values measured during heating and cooling. Near $16 \% \mathrm{In}_{2} \mathrm{O}_{3}$ and between $1000 \mathrm{~K}$ and $1400 \mathrm{~K}$, the curves were nonlinear during heating. Between $30 \%$ and $70 \%$, the temperature dependencies were less and differences observed during heating and cooling were less than those at the lower indium concentrations. The electrical conductivities obtained on subsequent heating and cooling cycles reproduced the initial measurements and continued to show the same hysteresis. Above $1480 \mathrm{~K}$, the electrical conductivity became nearly temperature independent, with the same values both on heating and cooling. 


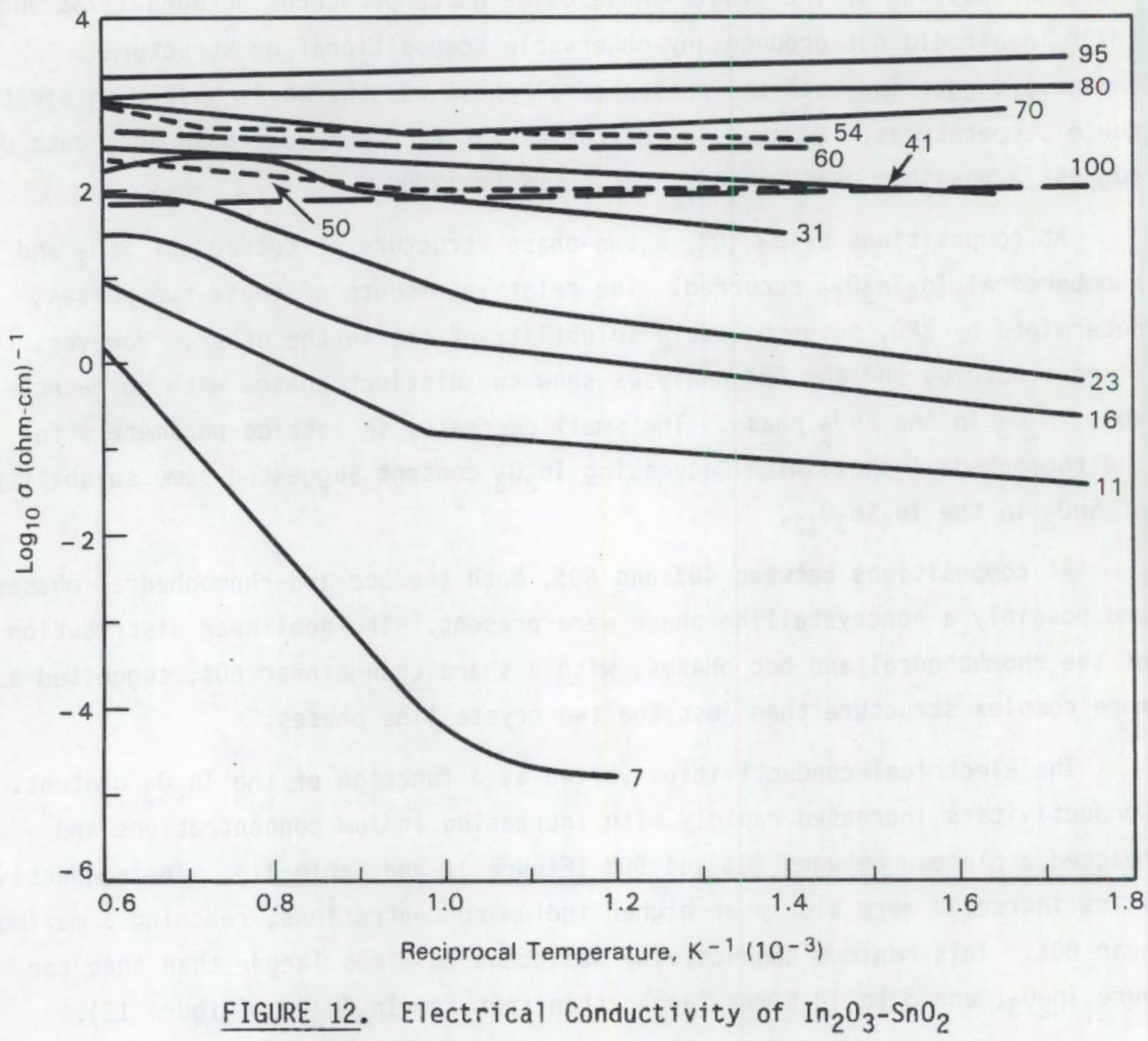

Above $80 \mathrm{~mol} \% \mathrm{In}_{2} \mathrm{O}_{3}$, for the bcc solid solutions, conductivities were nearly temperature independent over the entire temperature range with the same values for heating and cooling. A single $\log \sigma$ versus $\mathrm{K}^{-1}$ curve describes the electrical conductivity over the entire temperature range; the electrical conductivity decreases with decreasing tin content. However, one $95 \mathrm{~mol} \% \mathrm{In}_{2} \mathrm{O}_{3}$ sample had electrical conductivities substantially greater than all other compositions. No explanation for this anomaly could be derived from the $x$-ray or microstructural data.

The activation energies also varied with composition. At low temperatures, the activation energies decreased rapidly with indium content, reaching 
TABLE 11. Electrical Conductivity values of $\mathrm{In}_{2} \mathrm{O}_{3}-\mathrm{SnO}_{2}$

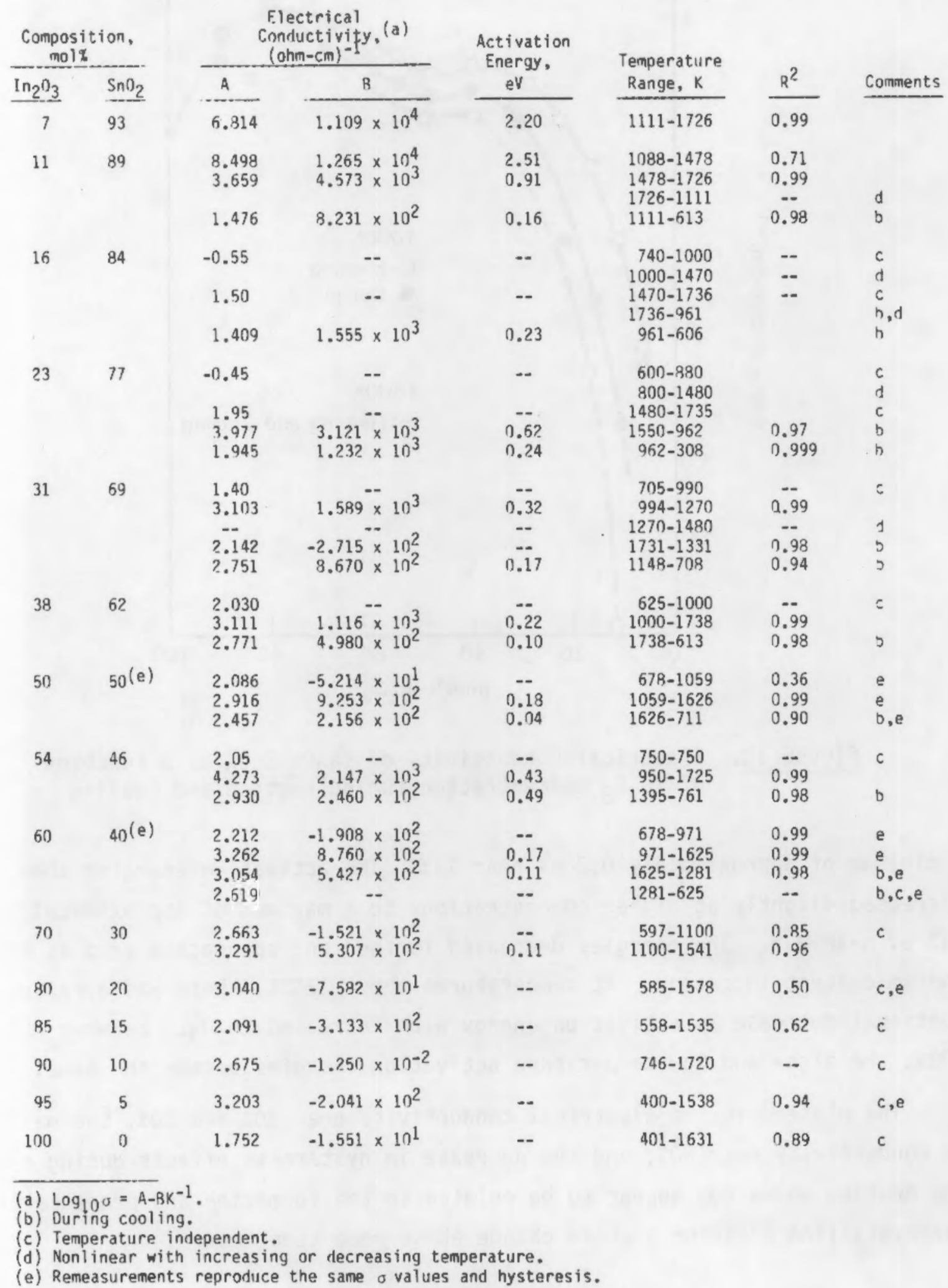




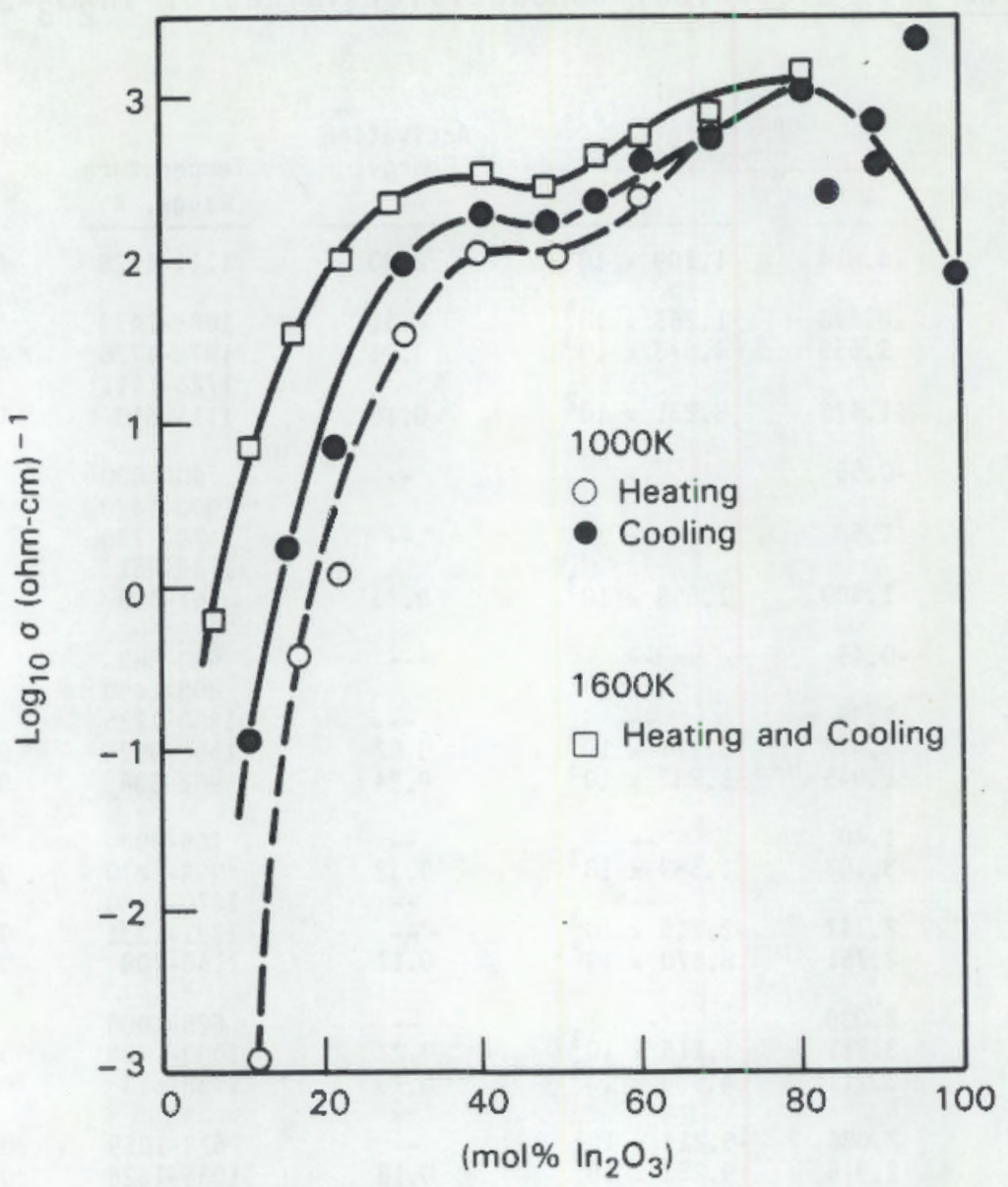

FIGURE 13. Electrical Conductivity of $\mathrm{In}_{2} \mathrm{O}_{3}-\mathrm{SnO}_{2}$ as a Function of $\mathrm{In}_{2} \mathrm{O}_{3}$ Concentration During Heating and Cooling

a minimum of approximately $0.2 \mathrm{eV}$ near $11 \%$. The activation energies then increased slightly at higher concentrations to a maximum of approximately $0.3 \mathrm{eV}$ near 23\%. The energies decreased further and approached zero as the indium content increased. At temperatures above 1200k, there was a rapid and continual decrease in activation energy with increased $\operatorname{In}_{2} \mathrm{O}_{3}$. Between $80 \%$ and $100 \%$, the high- and low-temperature activation energies became the same.

The plateau in the electrical conductivity near $30 \%$ and $50 \%$, the maximum in conductivity near $80 \%$, and the decrease in hysteres is effects during cooling and heating above $60 \%$ appear to be related to the formation and presence of the noncrystalline phase or a phase change above room temperature. 
The electrical properties are consistent with the formation of the rhombohedral $\mathrm{In}_{4} \mathrm{Sn}_{3} \mathrm{O}_{12}$ phase in air at $1873 \mathrm{~K}$. The data also suggest the presence of a noncrystalline phase between $11 \%$ and $80 \%$ and/or a phase change in this same compositional range between $1000 \mathrm{~K}$ and 1400K. Stoichiometry changes might also be expected with reduced oxygen pressures, producing changes in electrical transport property and structure. Both tin and indium oxides exhibited changes in electrical transport properties under reducing conditions.

Therefore, a rhombohedral $\mathrm{In}_{4} \mathrm{Sn}_{3} \mathrm{O}_{12}$ phase forms in air and is stable to 1873K. The electrical conductivity of this phase is 2 to 5 times greater than that for pure $\operatorname{In}_{2} \mathrm{O}_{3}$, but is $20 \%$ to $25 \%$ less than for the $80 \% \operatorname{In}_{2} \mathrm{O}_{3}$ (ss), which

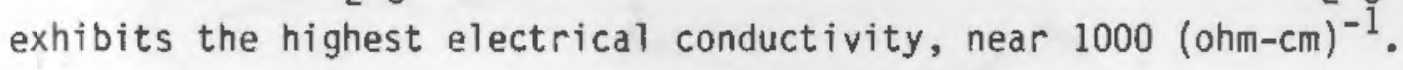

\section{$5.7 \mathrm{HfO}_{2}-\mathrm{RE}_{x} \mathrm{O}_{\mathrm{y}}-\left(\mathrm{In}_{2} \mathrm{O}_{3}-\mathrm{SnO}_{2}\right)$}

The electrical conductivities ( $\sigma$ ) of some $\mathrm{HfO}_{2}-\mathrm{PrO}_{2}-\mathrm{In}_{2} \mathrm{O}_{3}-\mathrm{SnO}_{2}$ compositions were measured in air to determine the effects of $\left(\mathrm{In}_{2} \mathrm{O}_{3}-\mathrm{SnO}_{2}\right)$ additions as a substitute for $\mathrm{In}_{2} \mathrm{O}_{3}$ alone to increase the electrical conductivity. The electrical conductivities from near room temperature to $1665 \mathrm{~K}$ for three compositions (Table 12) are shown in Figure 14. Significant differences in $\sigma$ were observed among these compositions, making it difficult to compare directly the substitutional effects of $\left(\mathrm{In}_{2} \mathrm{O}_{3}-\mathrm{SnO}_{2}\right)$ relative to $\mathrm{In}_{2} \mathrm{O}_{3}$. FC-99, with a total ( $\mathrm{In}_{2} \mathrm{O}_{3}-\mathrm{SnO}_{2}$ ) content of $12.5 \mathrm{~mol} \%$, had an electrical conductivity lower than that anticipated for a content of $12.5 \mathrm{~mol}_{2} \mathrm{In}_{2} \mathrm{O}_{3}$ but about the same as that for $9 \mathrm{~mol} \% \mathrm{In}_{2} \mathrm{O}_{3}$ base (see Figure 5). The conductivity and activation energies were, however, comparable to that of $0.266 \mathrm{HfO}_{2} \cdot 0.52 \mathrm{PrO}_{2}=0.172 \mathrm{In}_{2} \mathrm{O}_{3}(\mathrm{FC}-50-3)$. In addition, both FC-50-3 and FC-99 compositions showed the same electrical conductivities on heating and cooling, indicating good thermal stability.

TABLE 12. Composition of $\mathrm{HfO}_{2}-\mathrm{PrO}_{2}-\left(\mathrm{In}_{2} \mathrm{O}_{3}-\mathrm{SnO}_{2}\right)$

\begin{tabular}{|c|c|c|c|c|}
\hline & \multicolumn{4}{|c|}{ Composition, mol\% } \\
\hline & $\mathrm{HfO}_{2}$ & $\mathrm{PrO}_{2}$ & $\ln _{2} \mathrm{O}_{3}$ & $\mathrm{SnO}_{2}$ \\
\hline$F C-99$ & 35.3 & 52.2 & 9.1 & 3.4 \\
\hline$F C-100$ & 36.8 & 33.3 & 21.7 & 8.2 \\
\hline FCCP -80 & 21.6 & 32.0 & 11.8 & 34.6 \\
\hline
\end{tabular}




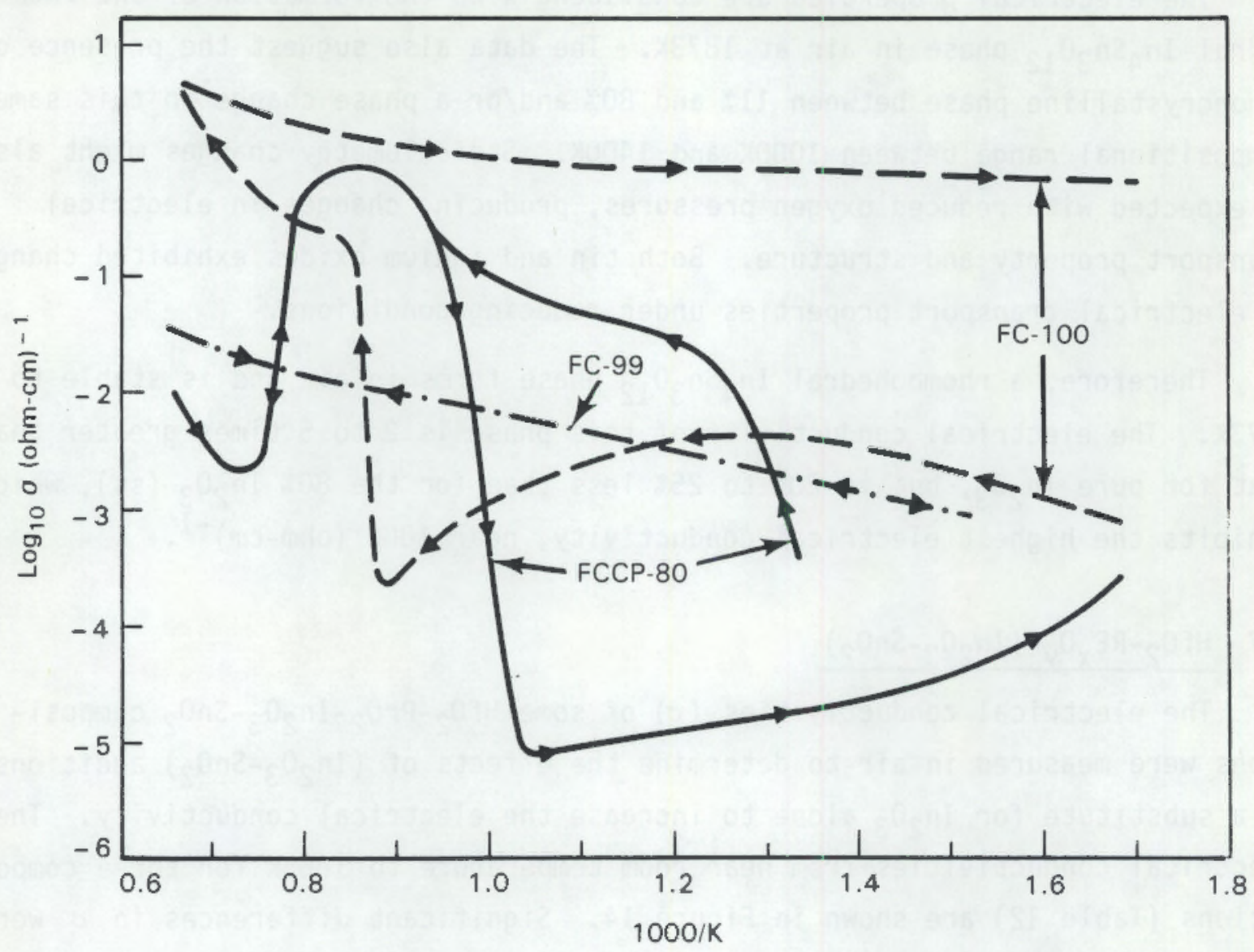

FIGURE 14. Electrical Conductivity of $\mathrm{HfO}_{2}-\mathrm{PrO}_{1.83}-\left(\mathrm{In}_{2} \mathrm{O}_{3}-\mathrm{SnO}_{2}\right)$

The compositions $\mathrm{FC}-100$ and $\mathrm{FCCP}-80$, which were higher in $\mathrm{SnO}_{2}$ and $\mathrm{In}_{2} \mathrm{O}_{3}$ than FC-99, exhibited large changes in conductivity on heating and cooling. These large changes in conductivity at higher temperatures suggest phase transformations. For FCCP-80, the transition above $1250 \mathrm{~K}$ was reversible, but irreversible below 1250K with lower values on cooling. For FC-100, the change was irreversible, with a significantly higher electrical conductivity on cooling. The electrical conductivity values for $\mathrm{FC}-100$ on cooling were about 10 times smaller than for a $\mathrm{SnO}_{2}$-free oxide containing $30 \mathrm{~mol} \% \mathrm{In}_{2} \mathrm{O}_{3}$ but essentially the same as that for $22 \mathrm{~mol} \% \operatorname{In}_{2} \mathrm{O}_{3}$ (see Figure 6 ). The conductivities were also about 10 times smaller than for a $0.351 \mathrm{HfO}_{2} \cdot 0.213 \mathrm{PrO}_{1.83} \cdot 0.036 \mathrm{Yb}_{2} \mathrm{O}_{3} \cdot 0.40 \mathrm{In}_{2} \mathrm{O}_{3}$ (AS-1) containing similar amounts of $\mathrm{PrO}_{1.83}$ and $\mathrm{HfO}_{2}$. 
The introduction of $\mathrm{SnO}_{2}$ appears to have caused hysteresis on heating and cooling. The substitution of $\left(\mathrm{In}_{2} \mathrm{O}_{3}-\mathrm{SnO}_{2}\right)$ for $\mathrm{In}_{2} \mathrm{O}_{3}$ in $\mathrm{HfO}_{2}-\mathrm{RE}_{x} \mathrm{O}_{y}$ did increase the electrical conductivity in a manner similar to that of $\mathrm{In}_{2} \mathrm{O}_{3}$ alone, but significantly more measurements would be needed to understand the effects of $\mathrm{SnO}_{2}$ addition. 



\subsection{MHD TEST CHANNEL}

An MHD test channel based on the graded ceramic component electrode was designed and assembled at PNL for testing in the Westinghouse Test Facility (WESTF) at Pittsburgh, Pennsylvania. The channel was delivered for testing but was never tested because of funding limitations. The design and assembly of the test channel is described in this section. The test incorporated materials described previously in this report.

The purpose of the MHD channel test was to determine the electrical and thermal characteristics of ceramic "superhot" electrodes based on the graded ceramic concept. Specifically, the test would: evaluate ceramic superhot electrodes surrounded by a metal fin; verify the electrode design parameters; and determine the thermomechanical performance and the extent of corrosion/erosion of the electrodes in an electric field when exposed to the slag, potassium seed, and sulfur-containing MHD environment. A simpler, preliminary test had been run previously using induced current and graded ceramic electrodes (Marchant and Bates 1980a).

The test channel consisted of eight electrodes (four anodes and four cathodes) with interelectrode refractory ceramic oxide insulators and refractory ceramic oxide side walls (Figure 16). The channel electrodes were instrumented with thermocouples to better define the thermal characteristics and determine the heat flow. The outside of the channel consisted of a stainless steel jacket, supplied by Westinghouse, which contained water passages for cooling during the test. The jacket was of one-piece construction, with holes in two opposite sides for inserting the electrodes. The inside dimensions of the jacket were $7.6 \mathrm{~cm}$ by $6 \mathrm{~cm}$. The length was $.37 .8 \mathrm{~cm}$. The diameter of the holes used to insert the electrodes was $3.2 \mathrm{~cm}$.

Because the channel was designed for hot wall operation, the jacket was lined on the inside with refractory ceramic oxide, which allows the inside surfaces to operate at temperatures above $1475 \mathrm{~K}$ (Figure 16). The high temperatures are necessary to minimize the amount of slag that might condense from the plasma. Previous hot ceramic electrode tests generally used hot electrodes in a channel with colder side walls or other areas; consequently, 
slag condensed on colder walls, then flowed over the hot electrodes and increased the corrosion of these electrodes.

The refractory ceramic oxide used to line the jacket was a fused cast magnesium oxide/magnesium oxide-aluminum oxide spinel (MMAS). The spinel, which was an experimental composition, was supplied by Applied Technology Laboratories(a) (Butte, Montana) and manufactured by Cohart (Louisville, Kentucky). The Cohart designation is $x-317$. The density of the MMAS is $3.37 \mathrm{~g} / \mathrm{cm}^{3}$ with an open porosity of 2 vol\%. The microstructure consists of magnesium oxide crystals within a matrix of spinel solid solution. The average thickness of the spinel was $12.1 \mathrm{~mm}$, covering both the electrode and side walls. The dimensions of the channel after lining were $3.6 \mathrm{~cm}$ by $52.1 \mathrm{~cm} ; 3.6 \mathrm{~cm}$ was the distance between the electrodes.

Originally in the form of bricks approximately $7.6 \mathrm{~cm} \times 7.6 \mathrm{~cm} \times 43 \mathrm{~cm}$, the MMAS was cut to shapes required for the channel. The centers of the bricks were porous due to the fuse casting process, so only the material near the outside of the brick could be used for the channel. The spinel lengths required to line each wall varied between 10 and $18 \mathrm{~cm}$. The joints between the pieces were rabbited to eliminate direct pathways between the plasma and the stainless steel jacket. The rabbiting also helped to produce interlocking joints to mechanically hold the MMAS pieces together.

The spinel was attached to the stainless steel walls by a heat-curable, silicone rubber adhesive (75 U, Dow Corning, Midland, Michigan). Before the adhesive was applied, the ceramic and stainless steel surfaces were cleaned with successive washes of trichlorethylene and acetone, then coated with a primer (1300, Dow Corning, Midland, Michigan). The adhesive was flattened into sheets about $0.018 \mathrm{~cm}$ thick and placed between the spinel and the channel. The adhesive was cured by heating to $427 \mathrm{~K}$ for 30 minutes in an oven. The post-cure treatment consisted of heating to $449 \mathrm{~K}$ for 4 hours. A silicone rubber insert placed inside the lined channel helped to hold the ceramic in place during curing. Since the jacket was one piece, the ceramic linings had to be slipped in

(a) Use of manufacturer names does not imply PNL endorsement. 
from the ends. The silicone adhesive was placed on the spinel, and the spinel was slipped into the channel.

The eight electrodes (four anodes and four cathodes) were mounted in the channel by inserting the electrode/insulator/water-cooling assembly (Figure 15) through holes in the jacket. The electrodes consisted of a cylindrical sintered ceramic body surrounded by a copper sleeve (Figures 15 and 16). The back face of the ceramic was in contact with copper metal mesh with a theoretical density near 50\%, which is attached to a copper water-cooling assembly. The copper sleeves were brazed to the cooling assembly with a braze containing 30 wt \% Ag, 20 wt \% Cd, 27 wt\% Cu, and 23 wt \% Zn (Easy-F10 30, Handy and Harmon, New York). The braze liquidus was $983 \mathrm{~K}$ and the solidus $878 \mathrm{~K}$. The brazing flux was WELCO Flux 250 (Welco Alloys, Madison Heights, Michigan). The brazing was done in air using a propane and air flame. An RTV silicone rubber

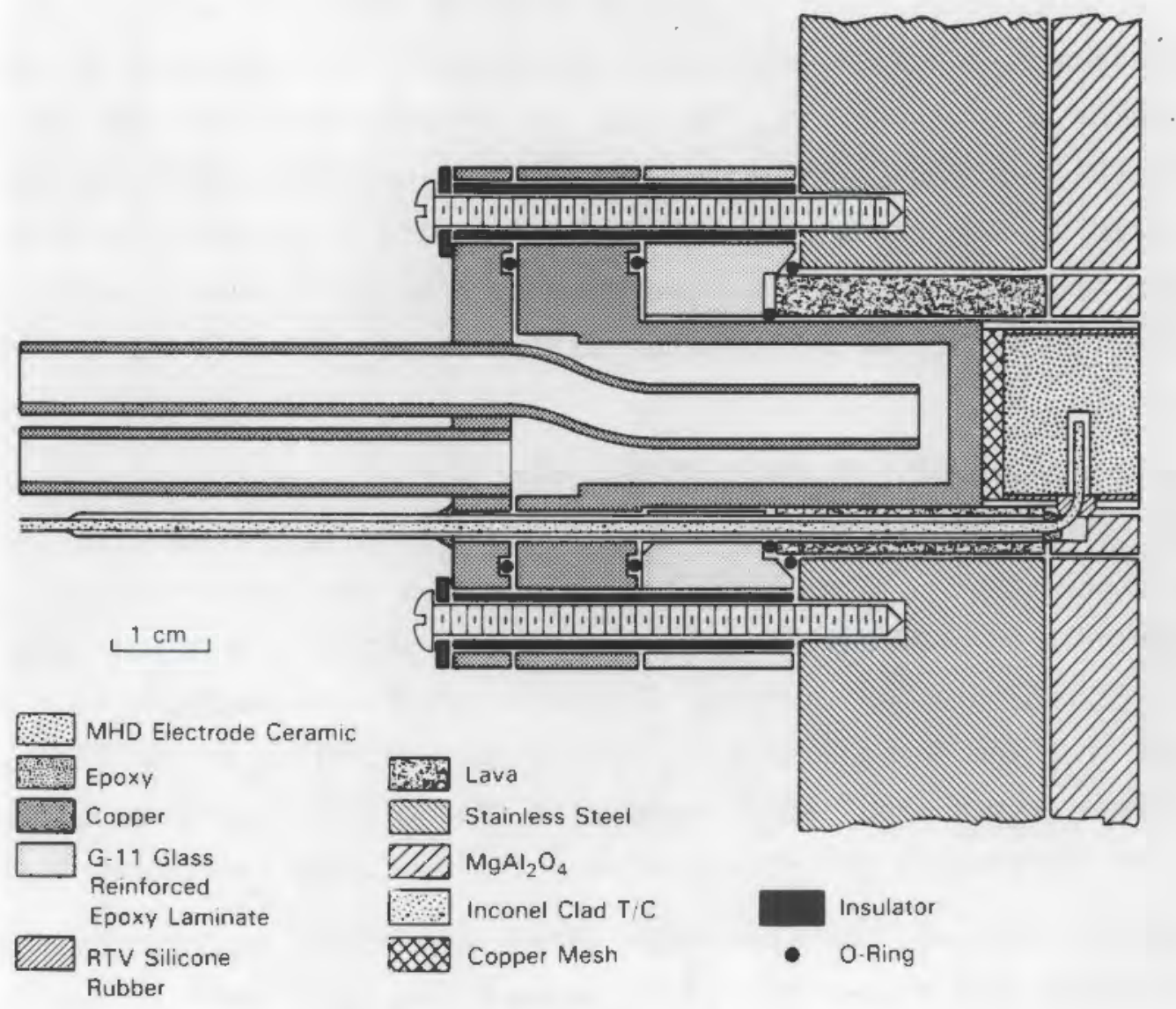

FIGURE 15. Cross Section of Electrode/Insulator and Water-Cooling Assembly 
(RTV 106, General Electric, Waterford, New York), containing 5 wt\% natural flake graphite, was used as the electrically conducting, flexible adhesive connecting the copper sleeve, copper mesh, and ceramic. This rubber has a maximum useful temperature of 573K.

The electrode compositions are listed in Table 13. The two electrodes based on hafnium oxide (positions 1 and 4 ) were composites containing a cap and a current leadout. The cap, in contact with the hot MHD plasma, was refractory and was of a composition to resist high-temperature corrosion. The electrical conductivity of the cap was only adequate at elevated temperatures. The current leadout was located between the cap and the copper mesh. The leadout was not as refractory or as corrosion resistant as the cap but had adequate electrical conductivity at room temperature. The cap and current leadout were of monolithic construction and were fabricated by sintering from reactive powders.

The two electrodes based on yttrium chromite (Table 13) were of one composition throughout, since the electrical conductivity was adequate over the temperature range of operation. Because the chromite materials are not as corrosion resistant at high temperatures as the hafnium oxide materials, the yttrium chromite electrodes were designed to operate at an electrode/plasma interface temperature about 150K lower than for the hafnium-based materials. The chromites were used as a reference because these materials had been tested previously.

Several electrodes contained alumel-chromel thermocouples that were ungrounded to an Incone 1600 sheath (SCAIN-040U-6, Omega Engineering, Inc., Stamford, Connecticut). The Inconel sheath limited the useful temperature of the thermocouple to $1422 \mathrm{~K}$. The center of the thermocouple hole was $0.76 \mathrm{~cm}$ from the electrode-channel surface. The depth of the thermocouple hole was designed so that the thermocouple tip was at the centerline of the electrode. The hole diameter was about $0.002 \mathrm{~cm}$ greater than the thermocouple $(0.1 \mathrm{~cm})$ to minimize the temperature difference between the electrode and thermocouple.

Inside the channel, the electrodes were electrically isolated by the spinel insulator (see Figure 16). An alumina-silica machinable ceramic was used between the copper cooling assembly and the stainless steel. The cooling 
TABLE 13. Electrodes for WESTF Test

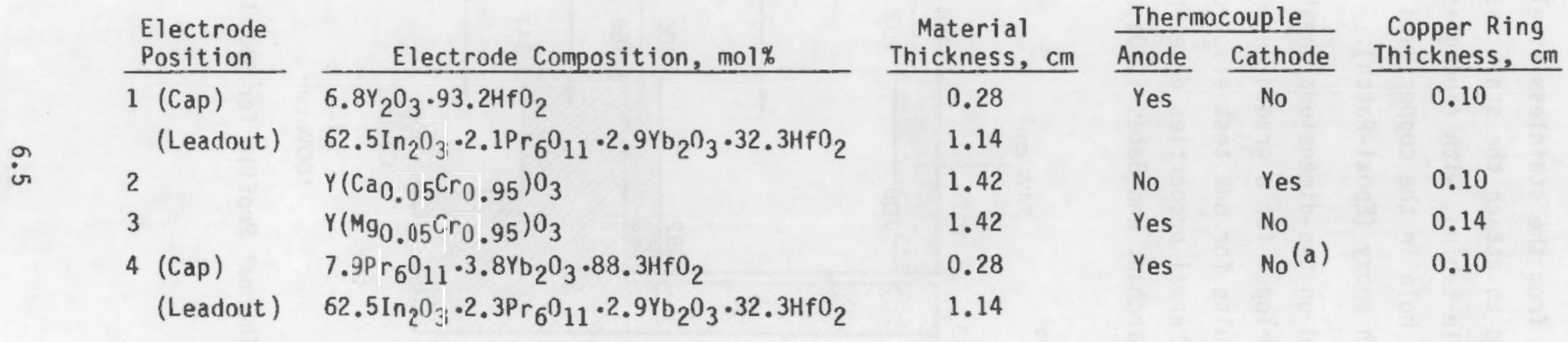

(a) Optical sight port. 
copper flange was separated from the stainless steel by a fiberglass-filled epoxy. The brass bolts used to attach the stainless steel to the copper were surrounded by heat shrinkable tubing, with fiberglass-filled epoxy washers placed under the head. The hole in the copper used for the thermocouple and alumina tube was sealed with epoxy (Epoxi-Patch).

A thermal profile based on two-dimensional heat flow and anticipated available heat flux was developed for a graded ceramic composite MHD electrode with a copper fin. The results for one test electrode are shown in Figure 16. The analysis was based on thermal properties developed and reported previously (Bates and Marchant 1978; Marchant and Bates 1980a,b).

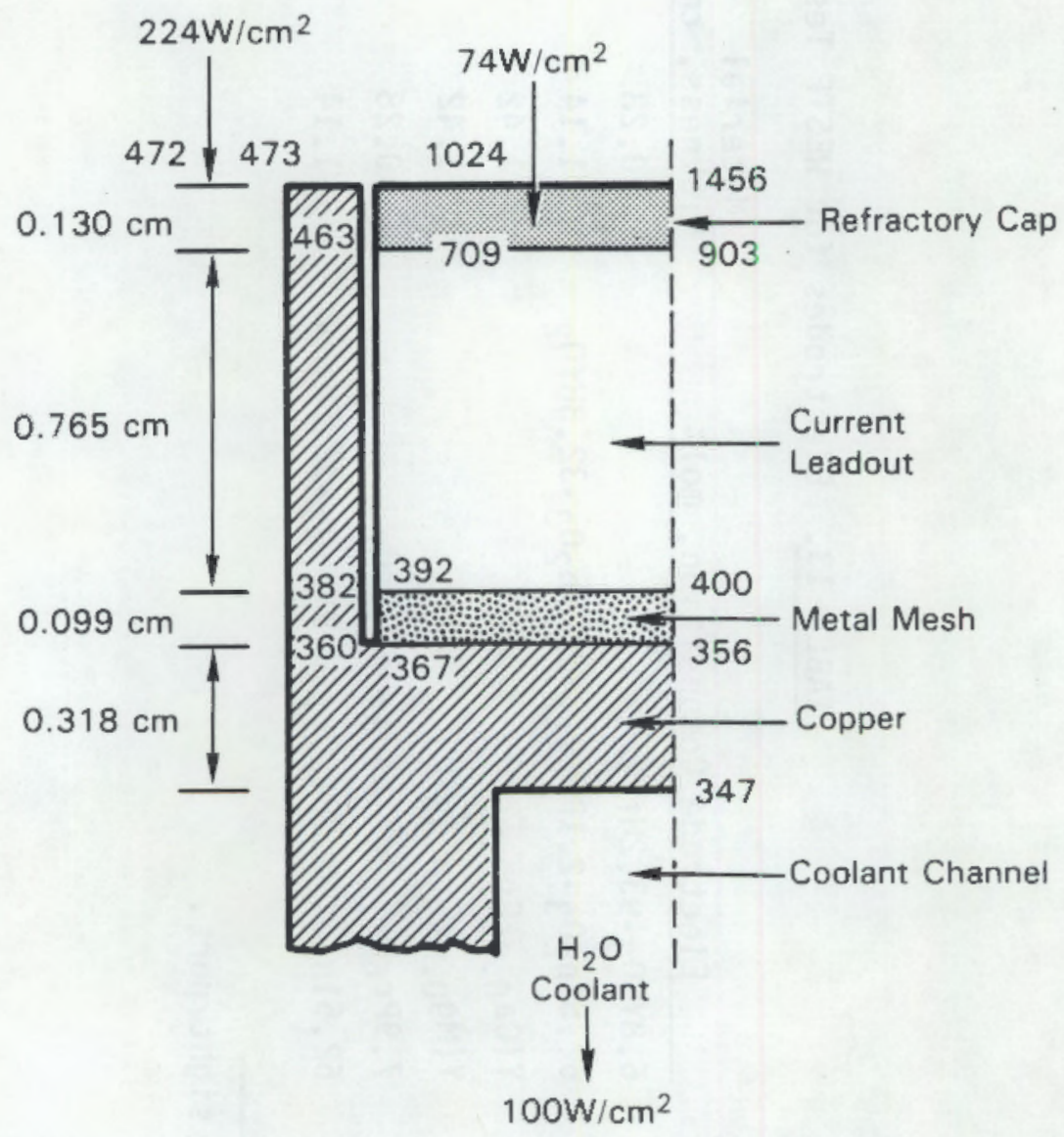

FIGURE 16. Thermal Profile for MHD Test Electrode 


\subsection{REFERENCES}

Anderson, H. U., R. Murphy, K. Humphrey, B. R. Rossing, A. Aldred, W. L. Procarione, R. J. Ackerman and J. L. Bates. 1978. "Influence of Composition and Cation Stoichiometry on the Volatility, Electrical Conductivity and ThermaT Expansion of $\mathrm{LaCrO}_{3}$ Based Oxides." The Rare Earths in Modern Science and Technology, Vol. 1. Ed. G. J. McCarthy and J.J. Rhyme. Plenum Press, New York, pp. 55-61.

Bates, J. L. 1969. Open-Cycle MHD Power Generation. Ed. J. B. Heywood and G. J. Womack. Pergamon Press, New York.

Bates, J. L. 1975. Characterization and Evaluation of Materials for the U.S. - U.S.S.R. MHD Program. BNWL-B-463, Quarterly Report for Period JulySeptember 1975. Pacific Northwest Laboratory, Richland, Washington.

Bates, J. L. 1976a. Characterization and Evaluation of Materials for the U.S. - U.S.S.R. MHD Program. BNWL-2004-1, Quarterly Report for Period OctoberDecember 1975. Pacific Northwest Laboratory, Richland, Washington.

Bates, J. L. 1976b. Characterization and Evaluation of Materials for the U.S. - U.S.S.R. MHD Program. BNWL-2004-2, Quarterly Report for Period JanuaryMarch 1976. Pacific Northwest Laboratory, Richland, Washington.

Bates, J. L. 1976c. Development and Characterization of Materials for OpenCycle MHD. BNWL-2004-3, Quarterly Report for Period April-June 1976. Pacific Northwest Laboratory, Richland, Washington.

Bates, J. L. 1976d. Development, Characterization and Evaluation of Materials for Open-Cycle MHD. BNWL-2004-4, Quarterly Report for Period July-September 1976. Pacific Northwest Laboratory, Richland, Washington.

Bates, J. L. 1976e. Development, Characterization and Evaluation of Materials for Open-Cycle MHD. BNWL-2004-5, Quarterly Report for Period OctoberDecember 1976. Pacific Northwest Laboratory, Richland, Washington.

Bates, J. L. 1977a. Development, Characterization and Evaluation of Materials for Open-Cycle MHD. BNWL-2004-6, Quarterly Report for Period January-March 1977. Pacific Northwest Laboratory, Richland, Washington.

Bates, J. L. 1977b. Development, Characterization and Evaluation of Materials for Open-Cycle MHD. PNL-2004-7, Quarterly Report for Period July-September 1977. Pacific Northwest Laboratory, Richland, Washington.

Bates, J. L. 1977C. "Electrical Conductivity of Molten Coal Slags Containing Potassium Seed." Proceedings of the Sixteenth Symposium on Engineering Aspects of Magnetohydrodynamics. University of Pittsburgh, Pittsburgh, Pennsylvania. 
Bates, J. L. 1978a. Development, Characterization and Evaluation of Materials for Open-Cycle MHD. PNL-2004-8, Quarterly Report for Period January-March 1978. Pacific Northwest Laboratory, Richland, Washington.

Bates, J. L. 1978b. Development, Characterization and Evaluation Materials for Open-Cycle MHD. PNL-2004-9, Quarterly Report for Period ApriT-June 1978. Pacific Northwest Laboratory, Richland, Washington.

Bates, J. L. 1978c. Open-Cycle Magnetohydrodynamic Electrical Power Generation. Ed. M. Petrick and B. Y. Shumyatsky. Argonne National Laboratory, Argonne, Illinois.

Bates, J. L., and J. E. Garnier. 1981. "Electrical Conductivity of $\mathrm{MgAl}_{2} \mathrm{O}_{4}$ and $\mathrm{Y}_{3} \mathrm{~A}{ }_{5}{ }_{5}{ }_{12}{ }^{\circ}$ Comm. Amer. Cer. Soc., October, Pp. C-138- C-141.

Bates, J. L., C. W. Griffin and D. D. Marchant, 1981. Electrochemical Corrosion of Iron-Magnesium-Alumina Spinel (FMAS) in Molten Potassium Salts and Coal Slag. PNL-3627, Pacific Northwest Laboratory, Richland, Washington.

Bates, J. L., and D. D. Marchant. 1978a. Evaluation of Candidate Magnetohydrodynamic Materials for the U-02 Phase III Test. PNL-2738, Pacific Northwest Laboratory, Richland, Washington.

Bates, J. L., and D. D. Marchant. 1978b. "Thermal Properties of MHD Electrode Materials." Seventeenth Symposium on Engineering Aspects of Magnetohydrodynamics, pp. D.6.1-7.

Bates, U. L., and D. D. Marchant. 1979a. Development, Characterization and Evaluation of Materials for Dpen-Cycle MHD. PNL-2004-10, Quarterly Report for Period October-December 1979. Pacific Northwest Laboratory, Richland, Washington.

Bates, J. L., and D. D. Marchant. 1979b. Development, Characterization and Evaluation of Materials for Open-Cycle MHD. PNL-2004-11, Quarterly Report for Period ApriT-June 1979. Pacific Northwest Laboratory, Richland, Washington.

Bates, J. L., and D. D. Marchant. 1979c. Development, Characterization and Evaluation of Materials for Open-Cycle MHD. PNL-2004-12, Quarterly Report for Period October-December 1979. Pacific Northwest Laboratory, Richland, Washington.

Bates, J. L., and D. D. Marchant, "Ceramic Component for Electrodes." U.S. Patent 4,229,322, October, 1980.

Bates, 3. L., and D. D. Marchant, "Ceramic Component for MHD Electrode," U.S. Patent 4,292,209, September, 1981. 
Bates, J. L., and D. D. Marchant. 1982a. Development, Characterization and Evaluation of Materials for Open-Cycle MHD. PNL-2004-13, Quarterly Report for Period October-December 1980. Pacific Northwest Laboratory, Richland, Washington.

Bates, J. L., and D. D. Marchant. 1982b. Development of Materials for OpenCycle MHD. PNL-4001-1, Quarterly Report for Period January-March 1981. Pacific Northwest Laboratory, Richland, Washington.

Bates, J. L., and D. D. Marchant. 1983a. Development of Materials for OpenCycle MHD. PNL-4001-2, Quarterly Report for Period October-December 1982 . Pacific Northwest Laboratory, Richland, Washington.

Bates, J. L., and D. D. Marchant. 1983b. Development of Materials for OpenCycle MHD. PNL-4001-3, Quarterly Report for Period January-March 1983. Pacif $\overline{i c}$ Northwest Laboratory, Richland, Washington.

Bates, J. L., and D. D. Marchant. 1983c. Development of Materials for OpenCycle MHD. PNL-4001-4, Quarterly Report for Period April-June 1983. Pacific Northwest Laboratory, Richland, Washington.

Bates, J. L., and G. B. Mellinger. 1975. "Thermal Diffusivity and Electrica? Conductivity of Molten And Solid Coal Slag." Sixth International Conference on Magnetohydrodynamic Electrical Power Generation, Washington, D.C., June 9-13, 1975, Vol. II - Open Cycle Components and Materia1s, CONF-750601PT II, pp. 7-14.

Bates, J. L., B. R. Rossing and H. K. Bowen. 1976. "MHD Electrode-Insulator Micro- and Macro-Structures." International Materials Symposium Microstructures of Ceramics. University of California, Berkeley, California, August 9-11, 1976.

Bates, J. L., W. Griffin, D. Marchant and J. E. Garnier. 1986. "Electrical Conductivity, Seebeck Coefficient and Structure of $\mathrm{In}_{2} \mathrm{O}_{3}-\mathrm{SnO}_{2} \cdot "$ Bul1. Am. Cer. Soc. 65(4):673-678.

Besson, J., C. Deportes and G. Robert. 1966. "Conductibilité electrique dans le systeme oxyde de hafnuim-oxide d'yttrium a'haute temperature." C. R. Acad. Sc. Paris 262(Series C):527-530.

Bowen, H. K. 1979. "Ceramics for Coal-Fired MHD Power." In Materials Science in Energy Technology. Ed. G. G. Libowitz and M. S. Whittingham. Academic Press, New York, pp. 181-199.

Bowen, H. K., and B. R. Rossing. 1976a. "Materials for Open Cycle Magnetohydrodynamics (MHD) Channels." In Critical Materials Problems in Energy Production. Ed. C. Stein. Academic Press, New York, pp. 335-356.

Bowen, H. K, and B. R. Rossing. 1976b. "Materials Problems in Open Cycle Magnetohydrodynamics." In Critical Materials Problems in Energy Production. Ed. C. Stein. Academic Press, New York, pp. 311-334. 
Cadoff, L. H., B. R. Rossing, D. D. Marchant and J. L. Bates. 1978. "Electrochemical Corrosion of Ceramic Materials in MHD Slag/Seed." Fourth U.S. U.S.S.R. Colloquium on MHD Power Generation, Washingtion, D.C., Dctober 5-6, 1978, CONF. 781009, pp. 689-711.

Glushkova, V. B., and V. A. Krzhizkanovskaya. 1973. "The Interaction of $\operatorname{In}_{2} \mathrm{O}_{3}$ with $\mathrm{ZrO}_{2}$ and $\mathrm{HfO}_{2}$ at $\mathrm{High}$ Temperatures." Colloques Internationaux C.N.R.S. No. 205 - Etude des Transformations Cristallines a Haute Temperature.

Johansen, H. A., and J. G. Cleary. 1964. "High Temperature Electrical Conductivity in the Systems $\mathrm{CaO}_{-} \mathrm{ZrO}_{2}$ and $\mathrm{CaO}_{-} \mathrm{HfO}_{2} \cdot$ " J. Electrochem Soc. III $1: 100-102$.

Kravchinskaya, M. V., A. K. Kuznetsov, P. A. Tikhonov and E. K. Koehler. 1973. "Phase Oiagrams of the Systems $\mathrm{HfO}_{2}-\mathrm{Pr}_{2} \mathrm{O}_{3}$ and $\mathrm{Dy}_{2} \mathrm{O}_{3}-\mathrm{Pr}_{2} \mathrm{O}_{3}$." Ceramurgia International 1:14-17.

Marchant, D. D., and J. L. Bates. 1980a. "Hafnia-Rare-Earth Oxides for High Temperature MHD Electrodes." Seventh International Conference on MHD Electrical Power Generation. Massachusetts Institute of Technology, Cambridge, Massachusetts, June 16-21, 1980, Vol. 1, pp. 287-291.

Marchant, D. D., and J. L. Bates. 1980b. "Rare-Earth Hafnium Oxide Materials for Magnetohydrodynamic (MHO) General Application." The Rare Earths in Modern Science and Technology, Vol. 2. Ed. G. J. McCarthy, J. J. Rhyme and H. B. Silber. Plenum Press, New York, pp. 553-558.

Marchant, D. D., C. W. Griffin and J. L. Bates. 1978. "Electrochemical Studies of MHD Channel Electrode Materials in Molten Potassium Salt and Coal Slags." Seventeenth Symposium on Engineering Aspects of Magnet ohydrodynamics, pp. D.5.1 - D.5.5.

Portnoi, K. N., N. I. Timofeeva, C. E. Salibekov and I. V. Romanovich. 1970. "Synthesis and Study of the Properties of Complex Oxides of the Rare Earths and Hafnium." IsZv. Akad. Nauk SSSR, Inorganic Materials 6 UCD 546.6521 + 545.832 21, January 1970, Pp. 91-95.

Romanov, A. I., V. E. Peletskii, F. A. Akopov, S. J. Schneider, G. P. Telegin and J. L. Bates. 1976. "Investigation of Thermophysical Properties of Refractory Materials Used in MHD Generator Channels." High Temperatures-High Pressures 8:199-208.

Saito, Y., T. Maruyama and Z. Kato. 1983. "Formation and Electrical Conductivity of Fluorite Solid Solution in the $\mathrm{HfO}_{2}-\mathrm{In}_{2} \mathrm{O}_{3}$ System." Zejt Physik Chemie Neve Fol ge 135(201):201-215. 
DISTRIBUTION

No. of

Copies

OFFSITE

$6 \mathrm{Mr}$. T. W. Arrigoni

Technical Project Officer PM-20, Mail Stop 920-L U.S. Department of Energy Pittsburgh Energy Technology Center

P.0. Box 10940

Pittsburgh, PA 15236

2 Mr. M. S. Mintz

U.S. Department of Energy

Advanced Energy Conversion Systems

FE-22, GTN

Washington, DC 20545

Office of Patent Counsel, DOE Chicago Operations Office 9800 South Cass Avenue

Argonne, IL 60439

30 Technical Information Center office of Scientific and

Technical Information

U.S. Department of Energy

P.0. Box 62

Oak Ridge, TN 37831

2 Or. W. R. Owens

Gilbert Associates, Inc. 19644 Club House Road

Suite $B 20$

Gaithersburg, MD 20879

Dr. W. Swift

Argonne National Laboratory

9700 S. Cass Avenue

Argonne, IL 60439

Dr. R. Kessler

Avco Research Laboratory, Inc. 2385 Revere Beach Parkway

Everett, MA 02149
No. of

Copies

Mr. S. Petty

Avco Research Laboratory, Inc. 2385 Revere Beach Parkway

Everett, MA 02149

Mr. P. B. Probert

Babcock and Wilcox Company

20 South Van Buren Avenue

P.0. Box 351

Barberton, OH 44203

Mr, F. Herbaty

Chicago Operations office

Technology Management Division

9800 S. Cass Avenue

Argonne, IL 60439

$\mathrm{Mr}$. A, C. Dolbec

Fossil Power Systems

Electric Power Research Institute

P.0. Box 10412

3412 Hillview Avenue

Palo Alto, CA 94303

$\mathrm{Mr}$. L. C. Angel 10

Electric Power Research Inst itute

P.0. Box 10412

3412 Hillview Avenue

Palo Alto, CA 94303

2 Ms. A. Dawson

Massachusetts Inst, of

Tech./PFC

NW 16-130

Cambridge, MA 02139

Dr. W. S. Shephard

Mississippi State University

MHD Energy Center

P.0. Drawer MM

Mississippi State, MS 39762 
No. of

Copies

Dr. R. Rosa

Montana State University

Department of Mechanical Engrg.

Bozeman, MT 59715

Mr. J. Sherick

Mountain States Energy, Inc.

P.0. Box 3767

Butte, MT 59702

Mr. G. Staats

Mountain States Energy, Inc.

P.0. Box 3767

Butte, MT 59702

Dr. C. Kruger

Stanford University

Stanford, CA 94305

Mr. S. T. Demetriades

STD Corporation

P.0. Box "C"

Arcadia, CA 91006

Mr. C. Maxwel1

STD Corporation

P.0. Box "C"

Arcadia, CA 91006

Dr. A. Solbes

TRW, Inc.

One Space Park

Redondo Beach, CA 90278

Mr. M. Bauer

TRW, Inc.

One Space Park

Redondo Beach, CA 90278
No. of

Copies

Dr. Y. C. L. Wu

Univ. of Tennessee Space Inst.

Tullahoma, TN 37388

$\mathrm{Mr}$. N. R. Johanson

Univ. of Tennessee Space Inst.

Tullahoma, TN 37388

Mr. G. L. Vivian

U.S. Department of Energy

Idaho Operations office

785 DOE Place

Idaho Falls, ID 83402

Mr. G. Parker

Westinghouse Electric

Corporation

Advanced Energy Systems

Division

P.0. Box 10864

Pittsburgh, PA 15236

ONSITE

2 DOE Richland Operations Office

D. R. Segna (2)

20 Pacific Northwest Laboratory

J. L. Bates (10)

E. L. Courtright

J. T. A. Roberts

P. L. Whiting

Technical Information (5)

Publishing Coordination (2) 